\title{
The $\mathrm{Ga}_{\mathrm{i}}$ AND $\mathrm{Ga}_{\mathrm{q}}$ Proteins Mediate the Effects of Melatonin on Steroid/Thyroid Hormone Receptor Transcriptional Activity and Breast Cancer Cell Proliferation
}

\author{
Ling Lai ${ }^{1}$, Lin Yuan ${ }^{1}$, Qi Chen ${ }^{1}$, Chunmin Dong ${ }^{1}$, Lulu Mao ${ }^{1}$, Brian Rowan ${ }^{1,2}$, Tripp Frasch ${ }^{1}$, \\ and Steven M. Hill ${ }^{1,2}$ \\ ${ }^{1}$ Department of Structural and Cellular Biology, Tulane University School of Medicine, New \\ Orleans, LA, USA \\ ${ }^{2}$ Tulane Cancer Center, Tulane University School of Medicine, New Orleans, LA, USA
}

\section{Abstract}

\begin{abstract}
Melatonin, via its MT1 receptor, but not the MT2 receptor, can modulate the transcriptional activity of various nuclear receptors (ERa and RARa, but not ER $\beta$ ) in MCF-7, T47D and ZR-75-1 human breast cancer cell lines. The anti-proliferative and nuclear receptor modulatory actions of melatonin are mediated via the MT1 G protein-coupled receptor expressed in human breast cancer cells. However, the specific $\mathrm{G}$ proteins and associated pathways involved in nuclear receptor transcriptional regulation by melatonin are not yet clear. Upon activation, the MT1 receptor specifically couples to the $\mathrm{G}_{\mathrm{ai} 2}, \mathrm{G}_{\mathrm{ai} 3}, \mathrm{G}_{\mathrm{aq}}$ and $\mathrm{G}_{\mathrm{all}}$ proteins, and via activation of $\mathrm{G}_{\mathrm{ai} 2}$ proteins, melatonin suppresses forskolin-induced cyclic AMP (cAMP) production, while melatonin activation of $\mathrm{G}_{\mathrm{aq}}$, is able to inhibit phospholipid hydrolysis and ATP's induction of inositol triphosphate $\left(\mathrm{IP}_{3}\right)$ production in MCF-7 breast cancer cells. Employing dominant-negative (DN) and dominant-positive (DP) forms of these $G$ proteins we demonstrate that $G_{a i 2}$ proteins mediate the suppression of estrogen-induced ERa transcriptional activity by melatonin, while the $\mathrm{G}_{\mathrm{q}}$ protein mediates the enhancement of retinoid-induced RARa transcriptional activity by melatonin. However, the growth-inhibitory actions of melatonin are mediated via both $\mathrm{G}_{\mathrm{ai} 2}$ and $\mathrm{G}_{\mathrm{aq}}$ proteins.
\end{abstract}

\section{Keywords}

melatonin; G proteins; estrogen receptor alpha; breast cancer

\section{Introduction}

It has been shown that melatonin at physiologic concentrations inhibits the growth of ERapositive human breast cancer cell lines, including MCF-7 cells [1]. The majority of the growth-inhibitory actions of melatonin on breast cancer cells appear to be mediated through the MT1 G protein-coupled membrane melatonin receptor [2]. Activation of MT1 melatonin receptors by melatonin appears to modulate a variety of G-proteins, which subsequently

Address reprint requests to Steven M. Hill, Department of Structural and Cellular Biology, Tulane University School of Medicine, 1430 Tulane Avenue, New Orleans, LA 70112, USA., ; Email: smhill@tulane.edu 
impact a variety of the signal transduction pathways. The heterotrimeric G-proteins activated by G protein-coupled receptors (GPCRs) generally release two groups of activating subunits: a GTP-bound form of the a subunit as well as a $\beta \gamma$ dimer [3], both can act individually or simultaneously as the signal transducers [4]. Considering the well-known function of Gprotein a subunits in GPCR signaling, this study focuses on the role of the Ga subunit on melatonin receptor-mediated signaling pathways. Each activated GTP-bound Ga subunit belongs to a different G-protein subfamily termed $G_{s}, G_{i}, G_{q}$ and $G_{12 / 13}$, which in turn act on individual effectors, including adenylate cyclase (AC), phosphodiesterase (PDE), phospholipase C (PLC) or ion channels to further affect the levels of associated second messengers such as cAMP, cGMP, inositol triphosphate $\left(\mathrm{IP}_{3}\right)$, and calcium [5]. Previous reports have demonstrated that melatonin, through activation of MT1 G protein-coupled melatonin receptor, regulates a number of these different downstream second messengers in a variety of tissues [6-14].

In MCF-7 breast cancer cells, we have previously reported that melatonin inhibits estrogen-, forskolin (Fsk)- or pituitary adenylate cyclase activating protein (PACAP) -induced increase of cAMP [7]. This inhibitory action appears to be mediated through the membrane $\mathrm{G}_{\mathrm{ai}}$ protein-coupled MT1 receptor, since in most cases the inhibitory effect of melatonin on cAMP levels is pertussis toxin (PTX)-sensitive [8]. Melatonin can blunt and/or block the stimulation of cAMP by forskolin or PACAP without prior stimulation of cAMP, but does not repress the basal level of cAMP $[9,10]$. Finally, our laboratory has previously reported that melatonin treatment enhances intracellular calcium levels $\left[\mathrm{Ca}^{2+}\right]_{\mathrm{i}}$ induced by ATP, implying the possible involvement of melatonin in phosphoinositol breakdown in MCF-7 breast cancer cells [15]. Also, MLT regulates ERa membrane signaling.

We [16] and others [17] have previously reported that melatonin can regulate the transcriptional activity of a number of steroid receptors, such as estrogen receptor alpha $(\mathrm{ERa})$, retinoic acid receptor alpha (RARa), glucocorticoid receptor (GR), and the retinoic acid related orphan receptor alpha (RORa) [16-20]. Kiefer et al. [7] demonstrated that the effects of melatonin on ERa transcriptional activity involve PTX-sensitive G-protein mechanisms. Currently, we have not delineated the specific G-proteins or the specific downstream signaling pathways through which melatonin differentially regulates the transcriptional activity of these steroid/thyroid hormone receptors. In the following set of experiments, we begin to define which G-proteins couple to the MT1 receptor and the specific second messengers (i.e. cAMP, cGMP, $\mathrm{IP}_{3}$, etc.) that transduce the effect of melatonin on steroid/thyroid hormone receptors to differentially modulate their transcriptional activity in MCF-7 cells.

\section{Materials and Methods}

\section{Materials}

All chemicals and tissue culture reagents were purchased from Sigma Chemical Co. (St. Louis, MO). RPMI 1640 medium was purchased from Cellgro (Mediatech, Inc., Herndon, VA). Fetal bovine serum (FBS) was purchased from Gibco-BRL (Grand Island, NY). The dominant-positive (DP) G-protein plasmids (DP-G $\mathrm{G}_{\mathrm{ai} 1}, \mathrm{G}_{\mathrm{ai} 2}, \mathrm{G}_{\mathrm{ai} 3}, \mathrm{G}_{\mathrm{aq}}$ and $\mathrm{G}_{11}$ ) and wildtype G-protein EE-tag expression vectors ( $D P \mathrm{G}_{\mathrm{ai} 1}, \mathrm{G}_{\mathrm{ai} 2}, \mathrm{G}_{\mathrm{ai} 3}, \mathrm{G}_{\mathrm{aq}}, \mathrm{G}_{\mathrm{a} 11}, \mathrm{G}_{0}$ and $\mathrm{G}_{\mathrm{z}}$ ) were 
purchased from Guthrie cDNA resource center (Sayre, PA). The dominant-negative (DN) Gprotein plasmids (DN-G $\mathrm{ai}_{\mathrm{ai}}, \mathrm{G}_{\mathrm{ai} 2}, \mathrm{G}_{\mathrm{ai} 3}, \mathrm{G}_{\mathrm{aq}}, \mathrm{G}_{\mathrm{a} 11}$ and control vector $\mathrm{G}_{\mathrm{aiR}}$ ) were purchased from Cue Biotech (Chicago, IL). Anti-G-protein polyclonal rabbit antibodies $\left(\mathrm{G}_{\mathrm{ai} 1}, \mathrm{G}_{\mathrm{ai} 2}\right.$, $\mathrm{G}_{\mathrm{ai} 3}, \mathrm{G}_{\mathrm{q}} \mathrm{G}_{0} \mathrm{G}_{\mathrm{az}}$, and $\mathrm{G}_{12}$ ) and an anti- $\mathrm{G}_{\mathrm{a} 16}$ goat polyclonal antibodies or anti $\mathrm{G}_{\mathrm{ai}}$-mouse monoclonal antibody were purchased from Santa Cruz Biotechnology (Santa Cruz, CA). The ERa antibodies H222 and C134 were purchased from Abbott Laboratories, Abbott, IL.

\section{Cell culture, expression plasmids and HRE reporter constructs}

The MCF-7, T47D, and ZR-75-1 human breast cancer cells, obtained from the laboratory of the late William L. McGuire (San Antonio, TX) were grown in RPMI 1640 medium supplemented with 10\% FBS, $50 \mathrm{mM}$ nonessential amino acids, $2 \mathrm{mM} \mathrm{L-glutamine,} 1 \mathrm{mM}$ sodium pyruvate, $10 \mathrm{mM}$ basal medium eagle (BME), $100 \mathrm{U} / \mathrm{ml}$ penicillin, and $100 \mu \mathrm{g} / \mathrm{ml}$ streptomycin. Cells were maintained at $37^{\circ} \mathrm{C}$ in a humidified atmosphere of $95 \%$ air and $5 \%$ $\mathrm{CO}_{2}$.

The ERE-luciferase construct used for our ERa transcriptional activity studies was kindly provided by Dr. Carolyn Smith (Houston, TX), and contains three vitellogenin ERE's upstream to the SV40 promoter in the pGL2P luciferase reporter plasmid. The RAREluciferase construct for the RARa transcriptional activity studies was kindly provided by Dr. Elwood Linney (Durham, North Carolina) and contains three RAREs from the RAR $\beta$ gene upstream of the thymidine kinase promoter. The $\mathrm{PCMV} \beta$ galactosidase plasmid was kindly provided by Dr. Jean Lockyer (New Orleans, LA). The dominant-positive (DP) G-protein plasmids (DP-G $\mathrm{G}_{\mathrm{ai} 2}, \mathrm{DP}-\mathrm{G}_{\mathrm{ai} 3}, \mathrm{DP}-\mathrm{G}_{\mathrm{aq}}$, and DP- $\left.\mathrm{G}_{\mathrm{a} 11}\right)$ and wild type G-protein EE-tag expression vectors $\left(\mathrm{G}_{\mathrm{a} 11}, \mathrm{G}_{\mathrm{ai} 2}, \mathrm{Ga}_{\mathrm{i} 3}, \mathrm{G}_{\mathrm{aq}}, \mathrm{G}_{\mathrm{a} 11}, \mathrm{G}_{\mathrm{ao}}\right.$, and $\left.\mathrm{G}_{\mathrm{az}}\right)$, were purchased from Guthrie cDNA resource center (Sayre, PA). The pcDNA3.1 control vector was purchased from Invitrogen (Carlsbad, CA). The dominant-negative (DN) G-protein plasmids (DN$\mathrm{G}_{\mathrm{ai} 1 / 2}, \mathrm{DN}-\mathrm{G}_{\mathrm{ai3}}, \mathrm{DN}-\mathrm{G}_{\mathrm{aq}}$, and $\left.\mathrm{DN}-\mathrm{G}_{\mathrm{a} 11}\right)$ and control vector $\left(\mathrm{G}_{\mathrm{aiR}}\right)$ were purchased from Cue Biotech (Chicago, IL). The FuGENE transfection reagent was purchased from Roche (Indianapolis, IN).

\section{Transient transfection and luciferase assay}

MCF-7, T47D and ZR-75-1 human breast cancer cells were maintained in RPMI 1640 medium supplemented with $10 \%$ FBS, then grown in phenol red-free medium supplemented with 5\% CS-FBS for three days. The cells were then plated in 6-well plates at a density of $0.5 \times 10_{5}$ cells/well in the same media. On the following day, the cells were transiently transfected for 6-8 hours in serum-free medium with $400 \mathrm{ng} /$ well luciferase reporter construct (ERE-luciferase construct or RARE-luciferase construct), $100 \mathrm{ng} /$ well pCMV $\beta$ plasmid using the FuGENE transfection reagent. The ERE-luciferase reporter construct contains a region of the vitellogenin A2 promoter upstream of the adenovirus E1b-TATApromoter in the pGL2 basic luciferase reporter plasmid and was provided by Dr. Carolyn Smith (Houston, TX). Eight hours following transfection the cells were re-fed with 5\% CSFBS supplemented medium and administered the indicated treatment for an additional $18 \mathrm{~h}$ prior to preparation of cell extracts. For studies examining the inhibitory effect of melatonin on 17- $\beta$ estradiol $\left(\mathrm{E}_{2}\right)$ induction of ERa transcriptional activity, cells (MCF-7, T47D, or 
ZR-75-1) were treated with vehicle $\left(0.001 \%\right.$ ethanol), melatonin $(10 \mathrm{nM}), \mathrm{E}_{2}(1 \mathrm{nM})$ or pretreated with melatonin $(10 \mathrm{nM})$ for 30 min followed by $\mathrm{E}_{2}$.

For studies examining effects of melatonin on all-trans retinoic acid (atRA) induction of RARa transcriptional activity, breast cancer cell lines (MCF-7, T47D, and ZR-75-1) were treated with vehicle $(0.001 \%$ ethanol), melatonin $(10 \mathrm{nM})$, atRA $(1 \mathrm{nM})$, or melatonin and atRA simultaneously. The RARE-luciferase reporter construct contains three retinoic acid receptor response elements (RAREs) from the retinoic acid receptor-a (RARa) gene upstream of the thymidine kinase promoter in the $\mathrm{pW} 1$ luciferase reporter plasmid and was provided by Dr. Elwood Linney (Durham, North Carolina). Eighteen hours following treatment, the cells were harvested in lysis buffer (24 mM Tris, pH7.8, 2 mM EDTA, $2 \mathrm{mM}$ DTT, $10 \%$ glycerol, $1 \%$ Triton $\mathrm{X}-100$ ) for luciferase assays using the luciferase assay system (Promega, Madison, WI). Cellular protein concentration was measured using the BioRad protein assay kit (BioRad Laboratories, Hercules, CA), and $\beta$-galactosidase activity was measured by the o-nitrophenyl $\beta$-D-galactopyranoside (ONPG) assay. Luciferase assays were performed using a Model 2010 Luminometer (MGM instrument, Inc., Hamden, CT).

For each sample, the luciferase activity was normalized to both the protein concentration and the $\beta$-galactosidase activity.

In studies to determine which G proteins mediate melatonin's regulation of ERa and RARa transcriptional activity, MCF-7 cells were used as the model system and transfected with dominant negative (DN)- and dominant positive (DP)-G-proteins. For these studies MCF-7 cells transfected with DN-G-proteins were treated with vehicle ( $0.001 \%$ ethanol), melatonin $(10 \mathrm{nM}), \mathrm{E}_{2}(1 \mathrm{nM})$ or pre-treated with melatonin $(10 \mathrm{nM})$ for 30 min followed by $\mathrm{E}_{2}$ or treated with vehicle $(0.001 \%$ ethanol), melatonin $(10 \mathrm{nM})$, atRA $(1 \mathrm{nM})$, or melatonin and atRA simultaneously, while MCF-7 cells transfected with DP-G-proteins were treated with either vehicle ( $0.001 \%$ ethanol) $\mathrm{E}_{2}$ or atRA. Eighteen hours following treatment, the cells were harvested in lysis buffer and cellular proteins used in luciferase assays as described above. Parallel culture dishes were also set-up for protein extraction and analysis of DP or DN-G protein expression of transfected cells. Protein extraction and Western blot analyses for expressed $\mathrm{G}$ proteins were conducted as described above.

\section{Melatonin regulation of ERa and ER $\beta$ - transcriptional activity}

For these studies ERa/ß-negative HEK293 embryonic kidney cells were maintained in RPMI 1640 medium supplemented with 10\% FBS, then grown in phenol red-free medium supplemented with 5\% CS-FBS for three days. The cells were then plated in 6-well plates at a density of $0.5 \times 10_{5}$ cells/well in the same media. On the following day, the cells were transiently transfected for 6-8 hours in serum-free medium with $400 \mathrm{ng} / \mathrm{well}$ of ERa or ER $\beta$ and MT1, as well as $400 \mathrm{ng} /$ well of luciferase reporter construct (ERE-luciferase construct or RARE-luciferase construct), and $100 \mathrm{ng} /$ well pCMV $\beta$ plasmid using the FuGENE transfection reagent. Eight hours following transfection the cells were re-fed with 5\% CSFBS supplemented medium and treated with vehicle ( $0.001 \%$ ethanol), melatonin $(10 \mathrm{nM})$, $E_{2}(1 \mathrm{nM})$ or pre-treated with melatonin $(10 \mathrm{nM})$ for 30 min followed by $E_{2}$ for an additional $18 \mathrm{~h}$ prior to preparation of cell extracts. Luciferase assays were done as described above. 


\section{ERa phosphorylation assay}

MCF-7 cells were cultured in estrogen- and phosphate-free medium for $16 \mathrm{~h}$ prior to treatment. Cells were treated with either melatonin $(10 \mathrm{nM}), \mathrm{E}_{2}(1 \mathrm{nM})$ or transfected with a DP-G $\mathrm{G}_{\mathrm{ai} 2}$ expression construct in the presence of $\left[{ }^{32} \mathrm{P}\right]$-orthophosphate $(50 \mu \mathrm{Ci} / \mathrm{ml})$ for $4 \mathrm{~h}$. Cells were then rinsed in cold PBS and harvested in $40 \mathrm{mM}$ Tris-Hcl, $\mathrm{pH} 7.5,150 \mathrm{mM} \mathrm{NaCl}$ and $1 \mathrm{mM}$ EDTA. The cells were lysed for $1 \mathrm{~h}$ in $500 \mathrm{ml}$ of $50 \mathrm{mM}$ Tris-Hcl, $\mathrm{pH} 8.0,1 \%$ NP-40, 2\% Sarkosyl, $300 \mathrm{mM} \mathrm{NaCl}, 5 \mathrm{mM}$ EDTA, $100 \mu \mathrm{M}$ sodium vanadate, $10 \mathrm{mM}$ sodium molybdate, $20 \mathrm{mM}$ sodium fluoride, leupeptin, aprotinin and PMSF. The lysate was centrifuged at $12,000 \times \mathrm{g}$ for $10 \mathrm{~min}$ at $4^{\circ} \mathrm{C}$ and the supernatant used for immunprecipitation. Phosporylated ERa was measured by immunoprecipitating total ERa with the H222 ERa ( $2.5 \mu \mathrm{g})$ [Abbott Laboratories, Abbott Park, IL] and the resulting immunoprecipitate was run on a $12 \%$ polyacrylamide gel and electroblotted overnight onto Hybond-C membrane. The phosphorylation state of the ERa was determined by exposure of the membrane to the P5747 anti-phosphoserine antibody (Sigma-Aldrich) at a 1:300 dilution. Total ERa levels were determined using the C-134 Abbott anti-ERa antibody.

\section{Whole cell lysate preparation and Western blot analysis}

Whole cell lysates were extracted from MCF-7 breast cancer cells maintained in RPMI 1640 supplemented with $10 \%$ FBS. After washing with ice-cooled PBS, the cells were incubated in lysis buffer (50 mM Tris-HCl, pH7.5, $150 \mathrm{mM}$ sodium chloride, $1 \%$ Nonidet P40, $0.5 \%$ sodium deoxycholate, and protease inhibitors), homogenized by 10 strokes of a dounce homogenizer, and incubated for one hour at $4^{\circ} \mathrm{C}$. To remove the insoluble components, the homogenized suspension was centrifuged at $10,000 \times \mathrm{g}$ for $10 \mathrm{~min}$ at $4^{\circ} \mathrm{C}$. Whole cell lysates (70 $\mu \mathrm{g}$ per sample) were denatured in sample loading buffer (70 mM Tris pH6.8, $2 \%$ SDS, $4 \mathrm{M}$ urea, $40 \mathrm{mM}$ dithiothreitol, $10 \%$ glycerol, $0.05 \%$ bromophenol blue) for $5 \mathrm{~min}$ at $80^{\circ} \mathrm{C}$, separated by $10 \%$ SDS-polyacrylamide gel electrophoresis (PAGE), and then transferred onto a Hybond membrane (Hybond-ECL, Amersham pharmacia, NJ). The membranes were blocked with 5\% nonfat dry milk in TBS-T20 buffer (10 mM Tris, pH8.0, $150 \mathrm{mM} \mathrm{NaCl}$, and $0.2 \%$ Tween 20) for one hour at room temperature, and then incubated with a variety of anti-G-protein polyclonal antibodies $\left(\mathrm{G}_{\mathrm{ai} 1}, \mathrm{G}_{\mathrm{ai} 2}, \mathrm{G}_{\mathrm{ai} 3}, \mathrm{G}_{\mathrm{aq}}, \mathrm{G}_{\mathrm{a} 11}, \mathrm{G}_{\mathrm{ao}}\right.$, $\mathrm{G}_{\mathrm{az}}, \mathrm{G}_{\mathrm{a} 12}$, and $\mathrm{G}_{\mathrm{a} 16}$ ) (Santa Cruz Biotechnology, CA) (1:1000) with TBS-T20 containing $5 \%$ non-fat milk for one hour at room temperature. After several washes with TBS-T20 buffer, the membranes were incubated with horse radish peroxidase (HRP)-conjugated antirabbit IgG, HRP-conjugated anti-goat IgG, or HRP-conjugated anti-mouse IgG (Santa Cruz Biotechnology, CA) at a dilution of 1:2000 with TBS-T20 containing 5\% non-fat milk for 45 min. After several washes in TBS-T20 buffer, the immunoreactive proteins were visualized using enhanced chemiluminescence (ECL) detection reagents (Amersham Pharmacia, NJ) and exposure of membrane to Kodak BIOMAX film.

\section{Whole cell extracts and co-immunoprecipitation assays}

The MCF-7 cells stably transfected with and over-expressing the MT1 receptor (MT1MCF-7) were maintained in RPMI 1640 supplemented with 10\% FBS, and treated with 10 $\mathrm{nM}$ melatonin or vehicle $(0.001 \%$ ethanol) for $30 \mathrm{~min}$, then washed twice with ice-cold PBS. For melatonin-treated samples, all subsequent steps were performed in the presence of 10 
$\mathrm{nM}$ melatonin. The cells were incubated with lysis buffer (50 mM Tris- $\mathrm{HCl}, \mathrm{pH} 7.5,150 \mathrm{mM}$ sodium chloride, $1 \%$ Nonidet $\mathrm{P} 40,0.5 \%$ sodium deoxycholate and protease inhibitors), scraped with a rubber policeman and homogenized by 10 strokes of the dounce homogenizer. The homogenized cellular lysates were centrifuged at $12,000 \times \mathrm{g}$ for $10 \mathrm{~min}$ at $4^{\circ} \mathrm{C}$ and the supernatant was pre-adsorbed with $50 \mu \mathrm{l}$ protein A-agarose beads (Roche, Indianapolis, IN) for at least $3 \mathrm{~h}$ at $4^{\circ} \mathrm{C}$. The supernatant was centrifuged at $10,000 \times \mathrm{g}$ for $20 \mathrm{~s}$ at $4^{\circ} \mathrm{C}$. Whole cell lysates were incubated with the MT1 536 anti-body (kindly provided by Dr. Ralf Jockers, Paris, France) at a dilution 1:50 for one hour at $4^{\circ} \mathrm{C}$. Fifty microliters of protein A-agarose beads were added to the cell lysate, and the suspension was rotated overnight at $4^{\circ} \mathrm{C}$. After centrifugation for at $12,000 \times \mathrm{g}$ at $4^{\circ} \mathrm{C}$ for $20 \mathrm{sec}$, the beads were washed twice in lysis buffer at $4^{\circ} \mathrm{C}$ for $20 \mathrm{~min}$, followed by washes in a high salt washing buffer (50 mM Tris- $\mathrm{HCl}, \mathrm{pH} 7.5,500 \mathrm{mM}$ sodium chloride, $0.1 \%$ Nonidet P40, $0.05 \%$ sodium deoxycholate and protease inhibitors) for $20 \mathrm{~min}$ at $4^{\circ} \mathrm{C}$, then one wash in low salt washing buffer ( $50 \mathrm{mM}$ Tris-HCl, $\mathrm{pH} 7.5,0.1 \%$ Nonidet $\mathrm{P} 40,0.05 \%$ sodium deoxycholate and protease inhibitors) for $20 \mathrm{~min}$ at $4^{\circ} \mathrm{C}$. Finally, protein A-agarose beads were pelleted by centrifugation at $10,000 \times \mathrm{g}$ at $4^{\circ} \mathrm{C}$ for $20 \mathrm{~s}$, and denatured in $25 \mu \mathrm{l} \mathrm{sample}$ loading buffer as described above. The proteins were electrophoretically separated on a $15 \%$ SDS-PAGE and transferred onto Hybond membranes. The co-immunoprecipitated Gproteins were detected by Western blot analysis as described above using a variety of anti-Gprotein antibodies at a 1:500 dilution.

\section{Cyclic AMP radioimmunoassay}

MCF-7 cells grown in RPMI 1640 supplemented with 10\% FBS were seeded in 6-well plates at a density of $0.5 \times 10^{6}$ cells per well. On the day following plating, the cells were transiently transfected with either DN- or DP-G-proteins described as above. Twenty-four hours following transfection, the cells were rinsed and re-fed with serum-free RPMI 1640 for an additional $24 \mathrm{~h}$. The cells transfected with DN-G-proteins were pre-treated with 0.1 $\mathrm{mM}$ isobutylmethylxanthine (IBMX) for $10 \mathrm{~min}$, and then treated for $10 \mathrm{~min}$ with vehicle (0.1\% DMSO), melatonin (10 nM), forskolin $(1 \mu \mathrm{M})$, or melatonin and forskolin, simultaneously. Cells transfected with DP-G-proteins were pretreated with $0.1 \mathrm{mM}$ isobutylmethylxanthine (IBMX) for $10 \mathrm{~min}$ and then with either vehicle (0.1\% DMSO) or forskolin $(1 \mu \mathrm{M})$ for $10 \mathrm{~min}$. The cells were lysed in ice-cold $100 \%$ ethanol and cell lysates were centrifuged at $2000 \times \mathrm{g}$ for $15 \mathrm{~min}$ at $4^{\circ} \mathrm{C}$. The supernatants were concentrated in a Speed-Vac (Savant, Farmingdale, NY) and the dried extracts were re-suspended in $200 \mu \mathrm{l}$ of cAMP assay buffer (0.05 M acetate buffer, pH5.8) and 1:1000 dilution of extract was analyzed for cAMP levels using the cAMP- $\left[{ }^{125} \mathrm{I}\right]$ assay system (Amersham Pharmacia Biotech) as per the manufacturer's instructions.

\section{Cyclic GMP radioimmunoassay}

MCF-7 cells grown in RPMI 1640 supplemented with 10\% FBS were seeded in 6-well plates at a density of $0.5 \times 10^{6}$ cells per well. On the following day, the cells were rinsed with RPMI 1640 medium and pre-treated with $0.1 \mathrm{mM}$ IBMX for $10 \mathrm{~min}$, followed by a 10 min treatment with either vehicle (0.001\% DMSO), 5-cyclopropyl-2[1(2-fluoro-benzyl)-1Hpyraxolo[3,4-b]pyrimidine-4-ylamine (BAY 41-2272) at a concentration of $1 \mu \mathrm{M}$ (for 10 $\min )$, melatonin $(10 \mathrm{nM})$ or pre-treated with different doses of melatonin $\left(1 \mathrm{nM}^{\text {to }} 10 \mu \mathrm{M}\right)$ 
followed by BAY 41-2272 for $10 \mathrm{~min}$. After $10 \mathrm{~min}$ of BAY 41-2272 treatment the cells were lysed in ice-cold $100 \%$ ethanol and lysates were centrifuged at 2,000 $\times \mathrm{g}$ for $15 \mathrm{~min}$ at $4^{\circ} \mathrm{C}$. The supernatant was concentrated in a Speed Vac and dried extracts re-suspended in $200 \mu \mathrm{l}$ of cGMP assay buffer (0.05 M acetate buffer, pH5.8). A 1:1000 dilution of cell extract was analyzed for cGMP levels by using the cGMP- $\left[{ }^{125} \mathrm{I}\right]$ assay system (Amersham Pharmacia Biotech) as per the manufacturer's instruction.

\section{Inositol-1, 4, 5-trisphosphate $\left(\mathrm{IP}_{3}\right)$ assay}

MCF-7 cells grown in RPMI 1640 supplemented with 10\% FBS were seeded in 6-well plates at a density of $0.5 \times 10^{6}$ cells per well. On the following day, the cells were transiently transfected with either DN or DP-G-proteins described as above. Twenty-four hours following transfection, the cells were rinsed and re-fed with serum-free RPMI 1640 for an additional $24 \mathrm{~h}$. Twenty-four hours after transfection, cells were rinsed with RPMI 1640 medium and pre-incubated for $20 \mathrm{~min}$ in $10 \mathrm{mM} \mathrm{LiCl}$. The cells were pre-treated with either vehicle $(0.001 \%$ ethanol) or melatonin $(10 \mathrm{nM})$ for $30 \mathrm{~min}$ followed by $100 \mathrm{mM}$ ATP. After $20 \mathrm{~min}$ of treatment, the cells were lysed in 3\% ice-cold perchloric acid for $20 \mathrm{~min}$. The lysates were centrifuged at 2,000 $\times \mathrm{g}$ for $15 \mathrm{~min}$ at $4^{\circ} \mathrm{C}$. The supernatants were neutralized to $\mathrm{pH} 7.5$ with ice-cold $10 \mathrm{M} \mathrm{KOH}$, and centrifuged at $2,000 \times \mathrm{g}$ for $15 \mathrm{~min}$ at $4^{\circ} \mathrm{C}$. The resulting aqueous phase was analyzed using the Inositol-1, 4,5-triphosphate $\left(\mathrm{IP}_{3}\right)\left[{ }^{3} \mathrm{H}\right]$ assay system (Amersham Pharmacia Biotech, Little Chalfont Buckinghamshire, England) as per the manufacturer's instruction.

\section{Growth study}

MCF-7 cells were plated at a density of $1 \times 10^{4}$ cells/well in RPMI 1640 medium supplemented with $10 \%$ FBS in 6-well plates. Twenty-four hours after plating cells were transiently transfected with $50 \mathrm{ng} /$ well of the pcDNA3.1 control vector, DN-G or DP-Gprotein plasmids using the FuGENE transfection reagent in serum-free medium. After an $8 \mathrm{~h}$ transfection, the cells transfected with DN-G-proteins were re-fed with fresh serumcontaining medium and treated with either vehicle $(0.001 \%$ ethanol) or melatonin $(1 \mathrm{nM})$, while the cells transfected with DP-G-proteins were re-fed with fresh serum-containing medium and treated with vehicle $(0.001 \%$ ethanol) alone. After 7 days, the cells were harvested with PBS-EDTA, mixed with $2 \%$ trypan blue to determine cell viability, and viable cells were counted on a hemacytometer.

\section{Statistical Analysis}

Data were analyzed for statistical significance using a one-way ANOVA followed by Tukey's multiple comparison tests.

\section{Results}

We have previously demonstrated that melatonin can suppress estrogen-induced transcriptional activation of the ERa in MCF-7 breast cancer cells [7,16], however, we have not confirmed that this is seen in other ERa-positive human breast cancer cell lines. Therefore, we conducted ERE-luciferase reporter analysis to examine the ability of melatonin to repress $\mathrm{E}_{2}$-induced ERa transactivation in T47D and ZR-75-1 human breast 
tumor cell lines. As shown in Fig. 1, pre-treatment of MCF-7 cells with $10 \mathrm{nM}$ melatonin significantly blunted $\mathrm{E}_{2}$-induced ERa transcriptional activation by $42 \%$ in MCF-7 cells, $30 \%$ in T47D cells and 64\% in ZR-75-1 breast cancer cells. The suppression of ERa transcriptional activity by melatonin was significantly enhanced in ZR-75-1 cells as compared to T47D cells.

To determine if melatonin also represses $E_{2}$-induced ER $\beta$ transcriptional activity, we conducted ERE-luciferase reporter assays in HEK293 cells, which do not express endogenous ERa, ER $\beta$, MT1, or MT2 receptors. For these studies HEK293 cells were transiently transfected with expression constructs for ERa, ER $\beta$ and MT1 or MT2 as well as an ERE-luciferase reporter construct. As shown in Fig. 2, treatment of transfected HEK293 cells with $E_{2}(1 \mathrm{nM})$ did not alter ERE-luciferase activity in HEK293 cells transfected with only the ERE-luciferase reporter construct or the pcDNA3.1 vector. However, in cells transfected with the ERa construct, treatment with $1 \mathrm{nM} \mathrm{E}_{2}$ resulted in a 4.2-times increase in luciferase activity and pre-treatment of cells with $10 \mathrm{nM}$ melatonin significantly blunted ERa transcriptional activity by $41 \%$. However, $\mathrm{E}_{2}$ induced a 2.7 -times increase in ER $\beta$ transcriptional activity and this activity was not blunted by melatonin. When HEK293 cells were transfected with ERa and the MT2 melatonin receptor, $\mathrm{E}_{2}$ again induced a 4.6-times increase in ERa activity, but ERa transcriptional activity was not blocked by melatonin when the MT2 receptor was expressed.

The ERa demonstrates a basal level of phosphorylation in the absence of ligand, which increases approximately 3.0-times upon stimulation with $\mathrm{E}_{2}$. Analysis of the effect of melatonin and $D P-G_{\mathrm{ai} 2}$ protein expression on $\mathrm{E}_{2}$-induced $\mathrm{ERa}$ phosphoryation demonstrates that melatonin induces a marked decrease (56\%) in basal ERa phosphorylation (Fig. 3). In addition, expression of a DP- $\mathrm{G}_{\mathrm{ai} 2}$ protein also resulted in a marked diminution (38\%) in $\mathrm{E}_{2}$ stimulated ERa phosphorylation.

Our laboratory has previously demonstrated that the growth-inhibitory effects of melatonin on human breast tumor cells are largely mediated through the MT1 G-protein-coupled receptor [2]. To further clarify the MT1 receptor coupled signaling pathway(s) in breast cancer, we set out to identify which G-proteins coupled to the MT1 receptor in MCF-7 breast cancer cells. First, we identified the endogenous G-proteins expressed in MCF-7 cells using immuno (Western)-blot analyses (Fig. 4A). Using whole cell lysates from MCF-7 cells and a panel of anti-G-protein + subunit antibodies, numerous endogenous G-proteins were detected, including $\mathrm{G}_{\mathrm{ai} 1}, \mathrm{G}_{\mathrm{ai} 2}, \mathrm{G}_{\mathrm{ai} 3}, \mathrm{G}_{\mathrm{az}}, \mathrm{G}_{\mathrm{ao}}, \mathrm{G}_{\mathrm{aq}}, \mathrm{G}_{\mathrm{a} 11}$, and $\mathrm{G}_{\mathrm{a} 12}$. However, not all Gproteins appear to be expressed in MCF-7 cells, for example, the $\mathrm{G}_{\mathrm{a} 16}$ protein, previously reported to couple to the MT1 receptor in MT1-transfected HEK293 cells [21], was not expressed in MCF-7 cells.

Second, we examined which G-protein(s) couple to the MT1 receptor in MCF-7 cells. Considering the low level of expression of the endogenous MT1 receptor in MCF-7 cells, immunoprecipitation experiments were conducted in MT1-MCF-7 cells stably transfected with and over-expressing the human MT1 melatonin receptor and wild type of G-proteins. As shown in Fig. 4B, melatonin treatment stimulated the $\mathrm{G}_{\mathrm{ai} 2}, \mathrm{G}_{\mathrm{ai} 3}, \mathrm{G}_{\mathrm{aq}}$, and $\mathrm{G}_{\mathrm{a} 11}$ proteins, but not the $\mathrm{G}_{\mathrm{aO}}$ and $\mathrm{G}_{\mathrm{aZ}}$ to couple to and co-immunoprecipitate with the MT1 receptor. 
To demonstrate that the endogenously expressed G-proteins couple to the activated MT1 receptor, we repeated our co-immunoprecipitation studies in MT1-MCF-7 cells and treated the cells with either vehicle or $1 \mathrm{nM}$ melatonin for $30 \mathrm{~min}$. Fig. 4C shows that endogenously expressed $\mathrm{G}_{\mathrm{ai} 2}, \mathrm{G}_{\mathrm{ai} 3}, \mathrm{G}_{\mathrm{aq}}$ and $\mathrm{G}_{\mathrm{a} 11}$ proteins indeed couple to and co-immunoprecipitate with the melatonin-activated MT1 receptor in MCF-7 cells.

Melatonin has previously been shown in tissues other than the breast, to negatively regulate intracellular cAMP levels [6,8], and down-stream components of the cAMP-signaling pathway including PKA activity and CREB phosphorylation [22]. As well, $\mathrm{G}_{\mathrm{ai}}$ proteins are also known to negatively regulate cAMP signaling, including repressing Fsk-induced cAMP accumulation through PTX-sensitive mechanism [8]. Therefore, we employed a cAMP radioimmunoassay assay to determine if $\mathrm{MT} 1$ receptor-coupled $\mathrm{G}_{\mathrm{i}}$ or $\mathrm{G}_{\mathrm{q}}$ proteins are involved in mediating melatonin inhibition of cAMP levels induced by Fsk in MCF-7 breast cancer cells. As shown in Fig. 5, stimulation of MCF-7 cells with Fsk $(1 \mu \mathrm{M})$ induced an approximately eight-fold increase in cAMP levels. Treatment of MCF-7 cells with melatonin alone had no significant effect on basal levels of cAMP, however, pre-treatment of MCF-7 cells for 10 min with melatonin $(10 \mathrm{nM})$ significantly blunted (by $50 \%$ ) the increase in intracellular cAMP concentrations induced by Fsk. Furthermore, melatonin inhibition of forskolin-induced cAMP accumulation was blocked by the expression of $\mathrm{DN}^{-G_{\mathrm{ai} 1 / 2}}$, DN$\mathrm{G}_{\mathrm{ai} 3}$, and $\mathrm{DN}-\mathrm{G}_{\mathrm{a} 11}$ proteins, but not the $\mathrm{DN}-\mathrm{G}_{\mathrm{aq}}$ protein (Fig. $5 \mathrm{~A}$ ). Conversely, DP-G $\mathrm{G}_{\mathrm{ai} 2}$, DP- $G_{a i 3}$, and $D P-G_{a 11}$ proteins (Fig. $5 B$ ), but not the $D N-G_{a q}$ protein significantly inhibited Fsk-induced cAMP accumulation.

It has been reported that melatonin elevates the levels of cGMP in mammary tissue [23], but the effect of melatonin on the level of cGMP has not been examined in breast cancer cells. To test whether MT1 receptor activation modulates the cGMP signaling pathway, MCF-7 cells expressing endogenous MT1 receptor were incubated in the presence of the nonspecific inhibitor of phosphodiesterases IBMX and then treated with either DMSO, 5Cyclopropyl-2[1(2-fluoro-benzyl)]-1H-pyraxolo[3,4-b]pyrimdin-4-ylamine (BAY 41-2272), a known inducer of cGMP, melatonin or pre-treated with melatonin for 5 min followed by BAY 41-2272 [24]. BAY 41-2272 induced a significant 2.1-times increase in intracellular cGMP levels, while melatonin treatment alone $(10 \mathrm{nM})$ did not affect of the cGMP levels in MCF-7 cells. Furthermore, pre-treatment of cells with various doses of melatonin ( $1 \mathrm{nM}$ to $10 \mu \mathrm{M})$ did not affect the BAY 41-2272-induced elevation of intracellular cGMP levels, (data not shown).

Previous data from our laboratory has shown that melatonin can potentiate ATP-induced stimulation and accumulation of intracellular calcium $\left[\mathrm{Ca}^{2+}\right]_{\mathrm{i}}$ in MCF-7 breast cancer cells, but melatonin alone does not alter the basal levels of $\left[\mathrm{Ca}^{2+}\right]_{i}[15]$. This result suggests the

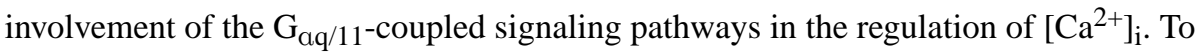
determine if $\mathrm{IP}_{3}$, or $\mathrm{G}_{\mathrm{aq} / 11}$ activated PLC pathway is modulated by melatonin, MCF-7 cells were pre-treated with $\mathrm{LiCl}$ for 20 min to block the degradation of $\mathrm{IP}_{3}$ as measured with the D-myo-inositol 1,4,5-trisphosphate assay. To evaluate the effect of melatonin on $\mathrm{IP}_{3}$ levels in MCF-7 cells, we examined the effect of melatonin on either basal levels of $\mathrm{IP}_{3}$ or ATPinduced $\mathrm{IP}_{3}$ levels. As shown in Fig. 6, stimulation of MCF-7 cells with $100 \mathrm{mM}$ ATP induced approximately a 3.0-times increase in $\mathrm{IP}_{3}$ levels. Melatonin $(10 \mathrm{nM})$ had no 
significant effect on basal $\mathrm{IP}_{3}$ levels, however, pre-treatment of MCF-7 cells for 5 min with melatonin $(10 \mathrm{nM})$ significantly blunted (by $52 \%$ ) the increase in $\mathrm{IP}_{3}$ levels induced by ATP. Furthermore, the expression of $\mathrm{DN}-\mathrm{G}_{\mathrm{aq}}$ and $\mathrm{DN}-\mathrm{G}_{\mathrm{a} 11}$ proteins, but not the $\mathrm{DN}-\mathrm{G}_{\mathrm{ai} 2}$ and $\mathrm{DN}-\mathrm{G}_{\mathrm{ai} 3}$ proteins blocked melatonin-induced inhibition of ATP-induced $\mathrm{IP}_{3}$ accumulation. Conversely, $D P-G_{a q}$ and $D P-G_{a 11}$ proteins, but not the $D P-G_{a i 2}$ and $D P-G_{a i 3}$ proteins, significantly inhibited ATP-induced $\mathrm{IP}_{3}$ levels by $50 \%$ and $59 \%$, respectively.

Previous reports have shown that melatonin can repress $\mathrm{E}_{2}$-induced ERa-dependent transcriptional activity in MCF-7 cells [7,16,25]. Since both PTX-sensitive and-insensitive G-proteins have been shown to couple to the MT1 receptor, we examined whether the functional coupling between MT1 receptor and specific G-proteins affects ERa transcriptional activity. Treatment of MCF-7 cells transfected with ERE-luciferase reporter construct and a control vector with melatonin produced no significant change in luciferase activity, whereas $\mathrm{E}_{2}$ treatment induced 3.46-times increase in luciferase activity (Fig. 7A). However, pre-treatment with melatonin for $30 \mathrm{~min}$. followed by $\mathrm{E}_{2}$ for 18 hours resulted in the $40 \%$ inhibition of ERa transcriptional activity compared to the cells treated with $1 \mathrm{nM}$ $\mathrm{E}_{2}$ (Fig. 7A). The expression of $\mathrm{DN}-\mathrm{G}_{\mathrm{ai} 2}$ protein, but not the $\mathrm{DN}-\mathrm{G}_{\mathrm{ai} 3}, \mathrm{DN}-\mathrm{G}_{\mathrm{aq}}$ or $\mathrm{DN}-\mathrm{G}_{\mathrm{a} 11}$ proteins blocked the ability of melatonin to repress $\mathrm{E}_{2}$-induced ERa transcriptional activity. Conversely, expression of a DP- $\mathrm{G}_{\mathrm{ai} 2}$ protein mimicked the inhibitory effect of melatonin, repressing $\mathrm{E}_{2}$-induced ERa transactivation by approximately $50 \%$ compared to control cells stimulated with $\mathrm{E}_{2}$ (Fig. 7B).

In order to elucidate whether melatonin can regulate RARa transcriptional activity through the G protein-coupled MT1 receptor and its associated G-protein signaling pathways, MCF-7 cells were transiently co-transfected with DN- or DP-G-proteins, and a RAREluciferase reporter construct and treated with vehicle ( $0.001 \%$ ethanol), melatonin $(10 \mathrm{nM})$, atRA $(1 \mathrm{nM})$, or melatonin followed by atRA as described in materials and methods. As shown in Fig. 8 in the cells transfected with the control G-protein vector, melatonin treatment alone did not modulate basal RARa transcriptional activity, while atRA stimulated a 3.46-times increase in luciferase activity. However, administration of melatonin $5 \mathrm{~min}$ prior to atRA, significantly enhanced atRA-induced RARa transactivation by approximately $54 \%$. The enhancement of atRA-induced RARa transactivation by melatonin was blocked by the expression of either $D N-G_{a q}$ or $D N-G_{a 11}$ proteins, but not $D N-G_{a i 1 / 2}$ or $D N-G_{a i 3}$ proteins (Fig. 8A). The expression of the constitutively active $D P-G_{a q}$ or DP-G $\mathrm{G}_{\mathrm{a} 11}$, but not DP- $\mathrm{G}_{\mathrm{ai} 2}$ or DP-G $\mathrm{G}_{\mathrm{ai} 3}$ proteins, mimicked the stimulatory effect of melatonin on atRAinduced RARa transactivation, and enhanced atRA-induced luciferase activity by $46 \%$ or $69 \%$, respectively (Fig. 8B).

We and others have reported that the growth of MCF-7 cells is suppressed by melatonin $[1,26]$. To define if G-proteins that mediate the actions of melatonin on steroid hormone receptor transcriptional activity also mediate the growth-suppressive effects of melatonin, MCF-7 cells were transfected with either a control vector or a plasmid for the expression of the various DN-G-proteins and treated with either vehicle $(0.001 \%$ ethanol) or melatonin (10 $\mathrm{nM}$ ) for 7 days. Fig. 9A demonstrates that melatonin significantly suppresses cell proliferation by $43 \%$ in MCF-7 cells transfected with the control vector. The expression of $\mathrm{DN}-\mathrm{G}_{\mathrm{ai} 2}, \mathrm{DN}-\mathrm{G}_{\mathrm{ai} 3}$, or DN-G $\mathrm{G}_{\mathrm{aq}}$ proteins blocked the growth-inhibitory activity of melatonin. 
To further establish the involvement of these G-proteins in the melatonin response pathway, we examined the effect of melatonin on MCF-7 cells transiently transfected with DP-Gproteins. Expression of either the DP-G $\mathrm{G}_{\mathrm{ai} 2}$ or $\mathrm{DP}-\mathrm{G}_{\mathrm{aq}}$ protein, but not $\mathrm{DP}-\mathrm{G}_{\mathrm{ai} 3}$ or $\mathrm{DP}-\mathrm{G}_{\mathrm{a} 11}$ protein, mimicked the inhibitory effect of melatonin on MCF-7 cell growth, suppressing cell numbers by $45 \%$ or $48 \%$, respectively (Fig. $9 \mathrm{~A}$ and B). Thus, the growth-inhibitory effect of melatonin on MCF-7 cells appears to be mediated via the activation of both $\mathrm{G}_{\mathrm{ai} 2}$ and $\mathrm{G}_{\mathrm{aq}}$ proteins.

\section{Discussion}

In this study, we employed human breast cancer cell lines that express endogenous MT1 receptor to demonstrate the different mechanisms regulating the transcriptional activity of ERa and RARa in response to melatonin and to elucidate the underlying signaling pathways leading to the growth-inhibitory actions of melatonin in breast cancer. The starting point for our study was to determine if melatonin modulated ERa transcriptional activity in human breast cancer cell lines other than MCF-7 cells and if melatonin also modulated the transcriptional activity of ER $\beta$. From our studies presented in figures 1 and 2, melatonin is able to repress $\mathrm{E}_{2}$-induced $\mathrm{ERa}$ transcriptional activity in three different ERa-positive MCF-7, T47D and ZR-75-1 cell lines, however, the actions of melatonin on ERa transcriptional activity was significantly greater in MCF-7 and ZR-75-1 cells as compared to T47D cells. This however, is not due to expression differences in the MT1 melatonin receptor in the two lines, as we have already demonstrated [27] that ZR-75-1 and T47D cells express equivalent levels of MT1 at the mRNA level, but both express somewhat lower levels of the MT1 receptor than the MCF-7 cells. We have previously reported that in a panel of 25 primary breast tumors, varying levels of MT1-melatonin receptor mRNA is expressed in the different breast tumors and breast cancer cell lines, with levels ranging from high, to very low. Furthermore, a recent report by Dillon et al. [28] has demonstrated that the melatonin MT1 receptor is expressed at different levels in different human breast tumors. Our current report is also the first to demonstrate that melatonin via its MT1 receptor, but not the MT2 receptor, represses $\mathrm{E}_{2}$-induced transcriptional activity of ERa, but not ER $\beta$.

We next set out to identify which G-proteins coupled to the MT1 receptor in MCF-7 breast cancer cells using co-immunoprecipitation assays. Our data demonstrate that the MT1 receptor couples with a limited set of G-proteins including: $\mathrm{G}_{\mathrm{ai} 2}, \mathrm{G}_{\mathrm{ai} 3}, \mathrm{G}_{\mathrm{aq}}$ and $\mathrm{G}_{\mathrm{a} 11}$ proteins, but does not couple with other G-proteins including $\mathrm{G}_{\mathrm{ai1}}, \mathrm{G}_{\mathrm{aO}}, \mathrm{G}_{\mathrm{az}}$, and $\mathrm{G}_{\mathrm{a} 12}$, which are also expressed in MCF-7 cells. The coupling of these G-proteins $\left(\mathrm{G}_{\mathrm{ai} 2}, \mathrm{G}_{\mathrm{ai} 3}, \mathrm{G}_{\mathrm{aq}}\right.$ and $\mathrm{G}_{\mathrm{\alpha} 11}$ ) is strictly melatonin dependent since MT1 receptor-G-protein complexes are not observed in the absence of melatonin. Our results confirm the previous report that $\mathrm{G}_{\mathrm{ai} 2}, \mathrm{G}_{\mathrm{ai} 3}$ and $\mathrm{G}_{\mathrm{aq} / 11}$ proteins coupled to the MT1 receptor in a melatonin-dependent and guanine nucleotide-sensitive manner in HEK293 cells expressing exogenous MT1 receptor [21].

Receptors with dual signaling properties often stimulate different pathways with different efficacy. In previous work, we reported that melatonin differentially regulates the transcriptional activity of steroid/thyroid hormone receptors, suppressing ERa, RORa and GR ligand-induced transcriptional activity while potentiating RARa-induced transcriptional activity in MCF-7 cells $[7,16]$. The concept that different G-proteins mediating different 
signaling pathways might be responsible for this differential response of nuclear receptors to melatonin is suggested by G-protein uncoupling studies using PTX treatment. Pre-treatment of MCF-7 breast cancer cells with PTX, which inhibits $\mathrm{G}_{i}$ protein function by ADPribosylation of the GDP-bounded a subunit of $\mathrm{G}_{\mathrm{i}}$ protein [29,30], effectively abrogates the inhibitory effect of melatonin on estrogen-dependent ERa transcriptional activity, but does not affect the stimulatory effect of melatonin on atRA-dependent RARa transcriptional activity in MCF-7 cells. As well, our current results indicate that multiple heterotrimeric Gproteins $\left(\mathrm{G}_{\mathrm{ai} 2}, \mathrm{G}_{\mathrm{aq}}\right.$ and $\left.\mathrm{G}_{\mathrm{a} 11}\right)$ are involved in regulating the differential melatonindependent modulation of ERa and RARa.

The above data indicate that $\mathrm{G}_{\mathrm{ai} 2}$ and/or $\mathrm{G}_{\mathrm{ai} 3}$ are effectors for melatonin's modulation of ERa signaling, whereas PTX-insensitive $\mathrm{G}_{\mathrm{aq}}$ and $\mathrm{G}_{\mathrm{a} 11}$ proteins are effectors for melatonin's modulation of RARa signaling pathway in breast cancer. Melatonin can inhibit Fsk-induced cAMP levels and ATP-induced $\mathrm{IP}_{3}$ levels, but does not affect cGMP levels in breast cancer cells. As for melatonin regulation of ATP-induced $\mathrm{IP}_{3}$ levels, this action is mediated via activation of $\mathrm{G}_{\mathrm{aq}}$ and $\mathrm{G}_{\mathrm{a} 11}$ proteins, but not $\mathrm{G}_{\mathrm{ai} 2}$ or $\mathrm{G}_{\mathrm{ai} 3}$ proteins. These results are consistent with previous reports demonstrating that melatonin can modulate several Gprotein-coupled intracellular signal pathways, including the cAMP [9], PKC/calcium [15,30], and MAP kinase cascades [31], which are the key second messengers in signaling systems known to modify the transcriptional activity of steroid receptors.

In breast cancer cells, it has been reported that activation of the cAMP signaling pathway can lead to ligand-dependent and ligand-independent phosphorylation of ERa, and stimulation of ERa transcriptional activity [32]. In sertoli cells, it has been reported that PKC activation can induce ligand-independent RARa transcriptional activity and modify ligand-dependent RARa transcriptional activity [33]. These studies demonstrate the critical connection of the different G-proteins to steroid hormone receptor transcriptional activity. Transient-transfection studies with DN- and DP-G-protein constructs demonstrate the specific action of $\mathrm{G}_{\mathrm{ai} 2}$ as the mediator of melatonin's effect on ERa transcriptional activity, and the role of $\mathrm{G}_{\mathrm{aq}}$ and $\mathrm{G}_{\mathrm{a} 11}$ as the mediators of melatonin's effect on RARa activity. Furthermore, the ability of a DP- $\mathrm{G}_{\mathrm{ai} 2}$ to mimic melatonin's suppression of $\mathrm{E}_{2}$-induced ERa phosphorylation, suggests that melatonin via the MT1 receptor and activation of $\mathrm{G}_{\mathrm{ai} 2}$ alters ERa transcriptional activity via modulation of ERa phosphorylation. This however, does not exclude the possibility of melatonin's modulation of ERa transcriptional activity through phosphorylation changes in ERa co-activators (CBP, Src-1 or Calmodulin).

It is well established that nuclear and steroid hormone receptors are targets for regulation by "cross talk" from other signaling pathways [34-36]. Modulation of G-proteins in MCF-7 cells by melatonin may result in the selective phosphorylation and activation of specific steroid/thyroid hormone receptors or other transcription factors. In these studies, we have attempted to establish whether the MT1-coupled G-proteins are responsible for inhibition of MCF-7 cell growth by using a selective competitive G-protein agonist and antagonist. First, the observation that PTX prevents melatonin-induced suppression of PC12 pheochromocytoma cancer cell growth strongly implies that the MT1 receptor via $G_{a i}$ proteins mediates the anti-proliferative action of melatonin [37]. Studies in which we overexpressed DN-G $\mathrm{G}_{\mathrm{ai} 2}$ and $\mathrm{DN}-\mathrm{G}_{\mathrm{aq}}$ suggest that not one, but both the $\mathrm{G}_{\mathrm{ai} 2}$ and $\mathrm{G}_{\mathrm{aq}}$ proteins 
play important roles in mediating melatonin's growth inhibitory activity in MCF-7 breast cancer cells.

We have previously reported that at least part of melatonin's anti-proliferative and $\mathrm{E}_{2}$ inhibitory effect on MCF-7 cells is mediated via suppression of $\mathrm{E}_{2}$ 's non-genomic induction of cAMP [7]. The above data suggests that the down-regulation of cAMP, by melatonin, may be an initiating biochemical event in suppressing breast cancer cell proliferation. This concept is supported by studies with PC12 pheochromocytoma cell A126-1B2-1 mutants with significantly diminished PKA activity (80\% reduction compared to controls), which is unresponsive to the growth-suppressive actions of melatonin [37].

To date, the exact pathway(s) downstream of the MT1 receptor that mediate breast cancer growth inhibition in MCF-7 cells, have not been definitively elucidated. Our findings demonstrate that the MT1 receptor-mediated growth-inhibitory effect of melatonin involves both the activation and suppression of the transcriptional activity of specific steroid/thyroid hormone receptors and their regulation of growth-modulatory genes via multiple G-protein coupled signal transduction pathways. In general, melatonin acts as an anti-mitogenic molecule suppressing ERa signaling and potentiating the transcriptional activity of RARa to inhibit breast tumor cell growth. Previous studies have already shown that melatonin cross talks with the estrogen signaling pathways in breast cancer, by inhibiting the expression of ERa mRNA via transcription-related events [18] decreasing the ERa-ERE complex binding stability [16], and further suppressing $\mathrm{E}_{2}$-induced ERa transcriptional activity of ERa [20]. A recent report by Del Rio et al. [25], has demonstrated that calmodulin (CaM) is essential for melatonin's suppression of ERa transcriptional activity. This work, does not conflict with our data demonstrating that melatonin mediates ERa transcriptional activity via activation of a $\mathrm{G}_{\mathrm{ai} 2}$ signaling pathway, as we have previously reported that melatonin can modulate $\mathrm{CaM}$ localization, shifting $\mathrm{CaM}$ from the nucleus to the cell membrane [15]. These data combined with numerous reports that $\mathrm{G}_{\mathrm{ai}}$ proteins can regulate many second messengers including cAMP and intracellular calcium, and CaM's reported actions as an ERa co-activator [25] suggest that melatonin modulation of CaM, although involved in regulation of ERa function, is clearly down-stream of melatonin's action on $\mathrm{G}_{\mathrm{ai} 2}$ proteins.

In MCF-7 cells, it has been shown that melatonin enhances atRA-induced RARa transcriptional activity using RARE-luciferase reporter assay without interfering with the expression of RARa [38]. The synergism between melatonin and the RARa signaling pathway was also demonstrated in the $\mathrm{N}$-nitroso- $\mathrm{N}$-methylurea (NMU)-induced rat mammary tumor model, where melatonin sensitizes not only the suppressive effect of retinoic acid on the incidence of NMU-induced mammary tumor [39], and also the regression of the carcinogen-induced mammary tumors [40].

In summary, we have demonstrated that melatonin inhibits $\mathrm{E}_{2}$-induced ERa transcriptional activity in a variety of human breast cancer cell lines, that this effect is specific for ERa and does not affect ER $\beta$, and that these effects are mediated via the MT1 and not the MT2 melatonin receptor. MCF-7 breast tumor cells were used to study the role of heterotrimeric G-protein subunits $\mathrm{G}_{\mathrm{ai} 2}$ and $\mathrm{G}_{\mathrm{aq}}$ as well as ERa and RARa activity in the growth of breast cancer cells as they are growth-inhibited by melatonin. Our studies employing DN- and DP- 
G-proteins show that melatonin differentially regulates ERa, but not ER $\beta$, and RARa transcriptional activity acting through different G-protein-dependent pathways by a mutant G-protein strategy. Although coupling to $\mathrm{G}_{\mathrm{ai} 2}$ may be essential for some of the actions of melatonin, stimulation of the RARa signaling pathways seems to require functional coupling between the activated MT1 receptor and the $G_{a q}$ protein family. Our results also suggest that melatonin may regulate breast cancer cell proliferation via these two separate, but interrelated, G-proteins and their downstream signaling partners (Fig. 9). Moreover, expression of the constitutively active mutants of $\mathrm{G}_{\mathrm{ai} 2}$ and $\mathrm{G}_{\mathrm{aq}}$ can promote growth inhibition in the absence of melatonin.

\section{Acknowledgments}

This work was supported by an NIH/NCI grant 5R01 CA 54152-14 to SMH.

\section{References}

1. Hill SM, Blask DE. Effects of the pineal hormone on the proliferation and morphological characteristics of human breast cancer cells (MCF-7) in culture. Cancer Res. 1998; 48:6121-6126. [PubMed: 3167858]

2. Yuan L, Collins AR, Dai J, Dubocovich ML, Hill SM. MT1 melatonin receptor overexpression enhances the growth suppressive effect of melatonin in human breast cancer cells. Mol Cell Endocrinol. 2002; 192:147-156. [PubMed: 12088876]

3. Bourne HR, Landis CA, Masters SB. Hydrolysis of GTP by the alpha chain of GS and other GTP binding proteins. Proteins. 1989; 6:222-230. [PubMed: 2516316]

4. Neer EJ, Clapham DE. Roles of G protein subunits in transmembrane signaling. Nature. 1988; 333:129-134. [PubMed: 3130578]

5. Birnbaumer L. Receptor-to-effector signaling through $\mathrm{G}$ proteins: roles for beta gamma dimmers as well as alpha subunits. Cell. 1992; 71:1069-1072. [PubMed: 1335363]

6. Olcese J. Cellular and molecular mechanisms mediating melatonin action: a review. Aging Male. 1998; 1:113-128.

7. Kiefer TL, Ram PT, Yuan L, Hill SM. Melatonin inhibits estrogen receptor transactivation and cAMP levels in breast cancer cells. Breast Cancer Res. Treat. 2002;; 71:37-45.

8. Godson C, Reppert SM. The $\mathrm{Mel}_{1 \mathrm{a}}$ melatonin receptor is coupled to parallel signal transduction pathways. Endocrinology. 1997; 138:397-404. [PubMed: 8977429]

9. Vanecek J, Vollrath L. Melatonin inhibits cyclic AMP and cyclic GMP accumulation in the rat pituitary. Brain Res. 1989; 505:157-159. [PubMed: 2558780]

10. Morgan PJ, Lawson W, Davidson G, Howell HE. Melatonin inhibits cyclic AMP in cultured ovine pars tuberalis cells. Mol Endocrinol. 1989; 5:R3-R8.X.

11. Faillace MP, Keller-Sarmiento MI, Rosenstein RE. Melatonin effect on the cyclic GMP system in the golden hamster retina. Brain Res. 1996; 711:112-117.X. [PubMed: 8680853]

12. Gilad E, Matzkin H, Zisapel N. Interaction of melatonin receptors by protein kinase C in human prostate cells. Endocrinology. 1997; 138:4255-4261.X. [PubMed: 9322938]

13. Gilad E, Pick E, Matzkin H, Zisapel N. Melatonin in benign prostate epithelila cells: evidence for the involvment of cholera and pertussis toxin-sensitive $\mathrm{G}$ proteins in their signal transduction pathways. Prostate. 1998; 35:27-34.X. [PubMed: 9537596]

14. Popova JS, Dubocovich ML. Melatonin receptor-mediated stimulation of phosphoinositide breakdown in chick brain slices. J Neurochem. 1995; 64:130-138.X. [PubMed: 7798906]

15. Dai J, Inscho EW, Yuan L, Hill SM. Modulation of intracellular calcium and calmodulin by melatonin in MCF-7 human breast cancer cells. J Pineal Res. 2002; 32:112-119. [PubMed: 12071468] 
16. Kiefer TL, Lai L, Burow ME, Hill SM. Differential regulation of estrogen receptor alpha, glucocorticoid receptor and retinoic acid receptor transcriptional activity by melatonin is mediated via the Gai2 protein. J Pineal Res. 2005; 38:231-239. [PubMed: 15813899]

17. Sommer S, Fuqua SA. Estrogen receptor and breast cancer. Semin Cancer Biol. 2001; 11:339-352. 2001. [PubMed: 11562176]

18. Molis TM, Spriggs LL, Hill SM. Modulation of estrogen receptor mRNA expression by melatonin in MCF-7 human breast cancer cells. Mol Endocrinol. 1994; 8:1681-1690. [PubMed: 7708056]

19. Molis TM, Spriggs LL, Jupiter Y, Hill SM. Melatonin modulation of estrogen-regulated proteins, growth factors, and proto-oncogenes in human breast cancer. J Pineal Res. 1995; 18:93-103. [PubMed: 7629697]

20. Ram PT, Kiefer T, Silverman M, Song Y, Brown GM, Hill SM. Estrogen receptor transactivation in MCF-7 breast cancer cells by melatonin and growth factors. Mol Cell Endocrinol. 1998; 141:5364. [PubMed: 9723886]

21. Brydon L, Roka F, Petit L, de Copet P, Tissot M, Barrett P, Morgan PJ, Nanoff C, Strosberg AD, Jockers R. Dual signaling of human Mel1a melatonin Receptors via Gi2, Gi3, and Gq/11 proteins. Mol Endocrinol. 1999; 13:2025-2037. [PubMed: 10598579]

22. Witt-Enderby PA, Masana MI, Dubocovich ML. Physiological exposure to melatonin supersensitizes the cyclic adenosine 3', 5'-monophosphate-dependent signal transduction cascade in Chinese hamster ovary cells expressing the human mt1 melatonin receptor. Endocrinology. 1998; 139:3064-3071. [PubMed: 9645677]

23. Cardinali DP, Bonanni-Rey RA, Mediavilla MD, Sanchez-Barcelo E. Dirunal changes in cyclic nucleotide response to pineal indoles in murine mammary glands. J Pineal Res. 1992; 13:111-116. [PubMed: 1336546]

24. Kalsi JS, Rees RW, Hobbs AJ, Royle M, Kell PD, Ralph DJ, Moncada S, Cellek S. BAY41-2272, a novel nitric oxide independent soluble guanylate cyclase activator, relaxes human and rabbit corpus cavernosum in vitro. J Urol. 2003; 169:761-766. [PubMed: 12544359]

25. Del, Rio B.; Garcia-Pedrero, JM.; Martinez-Campa, C.; Zuazua, P.; Lazo, PS.; Ramos, S. Melatonin: An endogenous specific inhibitor of estrogen receptor alpha via calmodulin. J Biol Chem. 2004; 279:38294-38302. [PubMed: 15229223]

26. Cos S, Sanchez-Barcelo E. Melatonin modulates growth factor activity in MCF-7 human breast cancer cell growth; influence of cell proliferation rate. Cancer Lett. 1995; 93:207-212. [PubMed: 7621430]

27. Ling L, Kiefer T, Burow M, Yuan L, Cheng Q, Hill SM. Gi and Gq proteins mediate the effects of melatonin on steroid receptor transcriptional activity. $95^{\text {th }}$ Annual Mtg. American Association for Cancer Research. 2004 Abst. 2335.

28. Dillon DC, Easley SE, Asch BB, Cheney RT, Brydon L, Jockers R, Winston JS, Brooks JS, Hurd T, Asch HL. Differential expression of high-affinity melatonin receptors (MT1) in normal and malignant breast tissue. Am J Clin Pathol. 2002; 118:451-453. [PubMed: 12219788]

29. Ui M, Katada T. Bacterial toxins as probe for receptor-Gi coupling. Adv Second Messenger Phosphoprotein Res. 1990; 24:63-69. [PubMed: 2169827]

30. McArthur AJ, Gillette MU, Prosser RA. Melatonin action and signal transduction in the rat suprachiasmatic circadian clock: activation of protein kinase $\mathrm{C}$ at dusk and dawn. Endocrinology. 1997; 138:627-634. [PubMed: 9002996]

31. Chan ASL, Lai FPL, Lo RKH, Voyno-Yasenetskaya TA, Stanbridge EJ, Wong YH. Melatonin MT1 and MT2 receptors stimulate c-Jun N-terminal kinase via pertussis toxin-sensitive and insensitive G proteins. Cell Signal. 2002; 14:249-157. [PubMed: 11812653]

32. Cho H, Katzenellenbogen BS. Synergistic activation of estrogen receptor-mediated transcription by estradiol and protein kinase activators. Mol Endocrinol. 1993; 7:441-452. [PubMed: 7683375]

33. Smith CL. Cross talk between peptide growth factor and estrogen receptor signaling pathways. Biol Reprod. 1998; 58:627-632. [PubMed: 9510949]

34. Braun KW, Vo MN, Kim KH. Positive regulation of retinoic acid receptor alpha by protein kinase $\mathrm{C}$ and mitogen-activated protein kinase in sertoli cells. Biol Reprod. 2002; 67:29-37. [PubMed: 12079996] 
35. Kato S, Masuhiro Y, Watanabe M, et al. Molecular mechanism of a cross-talk between oestrogen and growth factor signalling pathways. Genes Cells. 2000; 5:593-601. [PubMed: 10947845]

36. Lee YN, Park YG, Choi YH, Cho YS, Cho-Chung YS. CRE-transcription factor decoy oligonucleotide inhibition of MCF-7 breast cancer cells: cross-talk with p53 signaling pathway. Biochemistry. 2000; 39:4863-4868. [PubMed: 10769144]

37. Roth JA, Rosenblatt T, Lis A, Bucelli R. Melatonin-induced suppression of PC12 cell growth is mediated by its Gi coupled transmembrane receptors. Brain Res. 2001; 919:139-146. [PubMed: 11689171]

38. Eck-Enriquez K, Kiefer TL, Spriggs LL, Hill SM. Pathways through which a regimen of melatonin and retinoic acid induces apoptosis in MCF-7 human breast cancer cells. Breast Cancer Res Treat. 2000; 61:229-239. [PubMed: 10965999]

39. Teplitzky SR, Kiefer TL, Cheng Q, et al. Chemoprevention of NMU-induced rat mammary carcinoma with the combination of melatonin and 9-cis-retinoic acid. Cancer Lett. 2001; 168:155163. [PubMed: 11403920]

40. Melancon K, Cheng Q, Kiefer TL, et al. Regression of NMU-induced mammary tumors with the combination of melatonin and 9-cis-retinoic acid. Cancer Lett. 2005; 227:39-48. [PubMed: 16051031] 


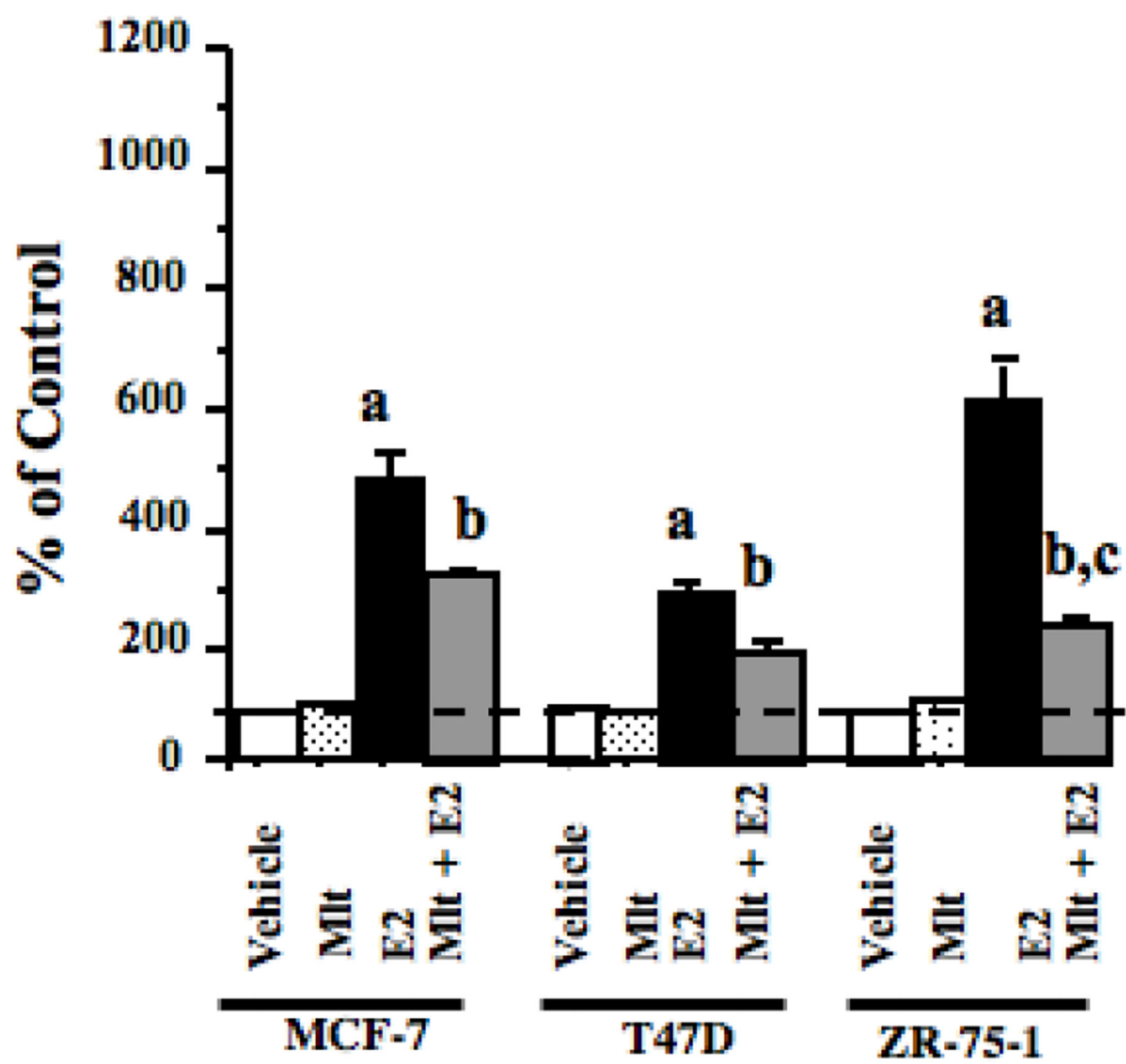

Fig. 1.

Effects of melatonin on ERa transcriptional activity in MCF-7, T47D and ZR-75-1 human breast cancer cells. MCF-7, T47D and ZR-75-1 breast cancer cells grown in phenol red-free medium supplemented with 5\% CS-FBS and were used to examine ERa transcriptional activity using an ERE-luciferase reporter construct as described in Materials and Methods with vehicle ( $0.001 \%$ ethanol), $10 \mathrm{nM}$ melatonin, $1 \mathrm{nM} \mathrm{E}_{2}$, or pretreated with melatonin for 30 min followed by $\mathrm{E}_{2}$. Luciferase activity was recorded as mean relative light units (RLUs). For comparison purposes between tumor cell lines diluent treated values were set at $100 \%$ and activity in response to other treatments was recorded as percent of control activity. $\mathrm{n}=3$ independent experiments; a, $P<0.05$ vs. control; $b, P<0.05$ vs. E2 alone. 

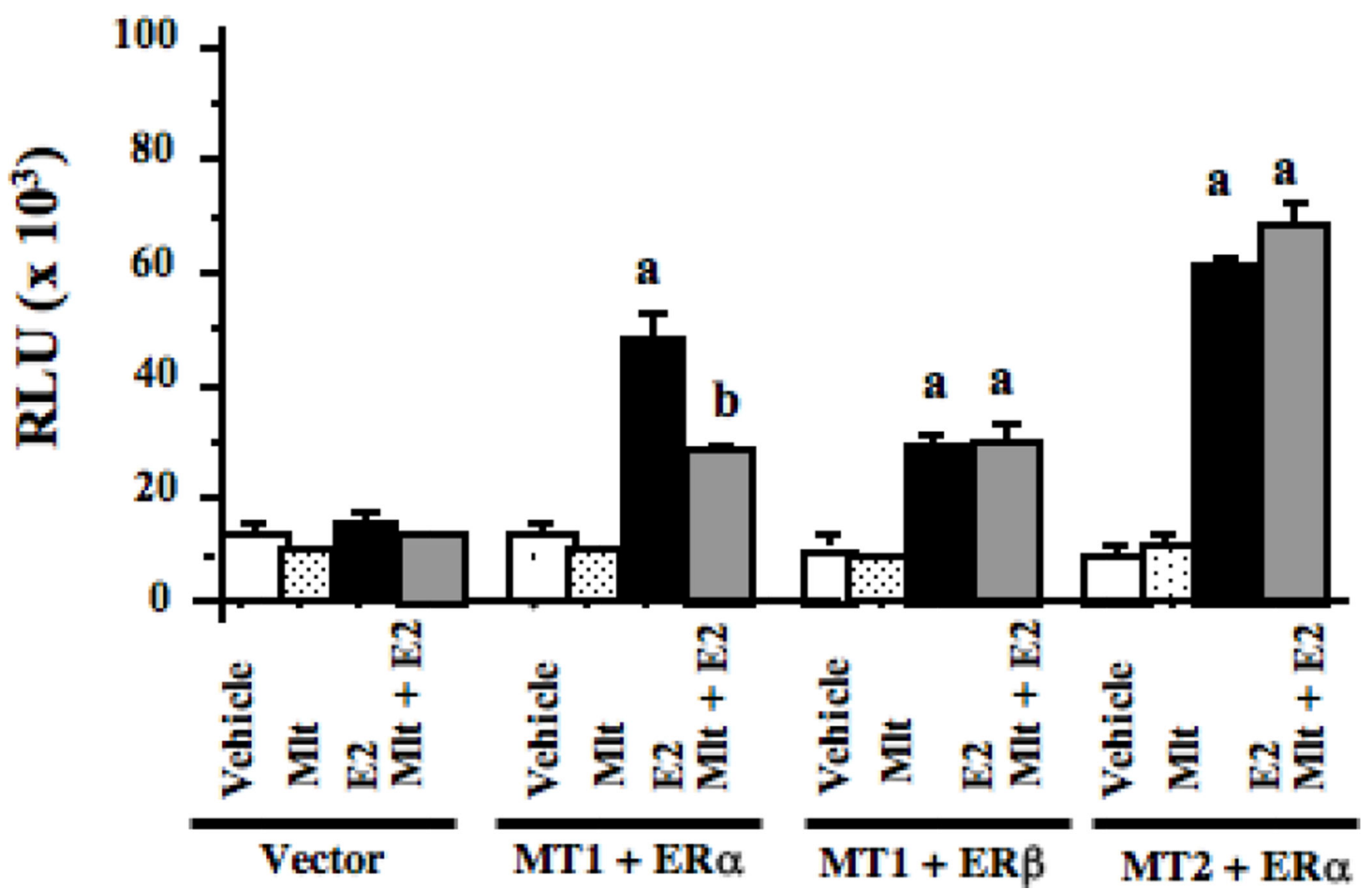

Fig. 2.

Effects of melatonin via MT1 and MT2 receptors on ERa and ER $\beta$ transcriptional activity in HEK293 embryonic kidney cells. HEK293 embryonic kidney cells were grown in phenol red-free medium supplemented with 5\% CS-FBS. After 3 days in media supplemented with $5 \%$ CS-FBS cells were transiently transfected with ERa or ER $\beta$, MT1 or MT2 cDNA expression vectors, an ERE-luciferase reporter construct and treated for $18 \mathrm{~h}$ with vehicle $(0.001 \%$ ethanol), $10 \mathrm{nM}$ melatonin, $1 \mathrm{nM} \mathrm{E}$, or pretreated with melatonin for $30 \mathrm{~min}$ followed by $\mathrm{E}_{2}$ as described in Materials and Methods. Luciferase activity was recorded as mean relative light units (RLUs). $\mathrm{n}=3$ independent experiments; a, $P<0.05$ vs. control; $b, P$ $<0.05$ vs. E2 alone. 

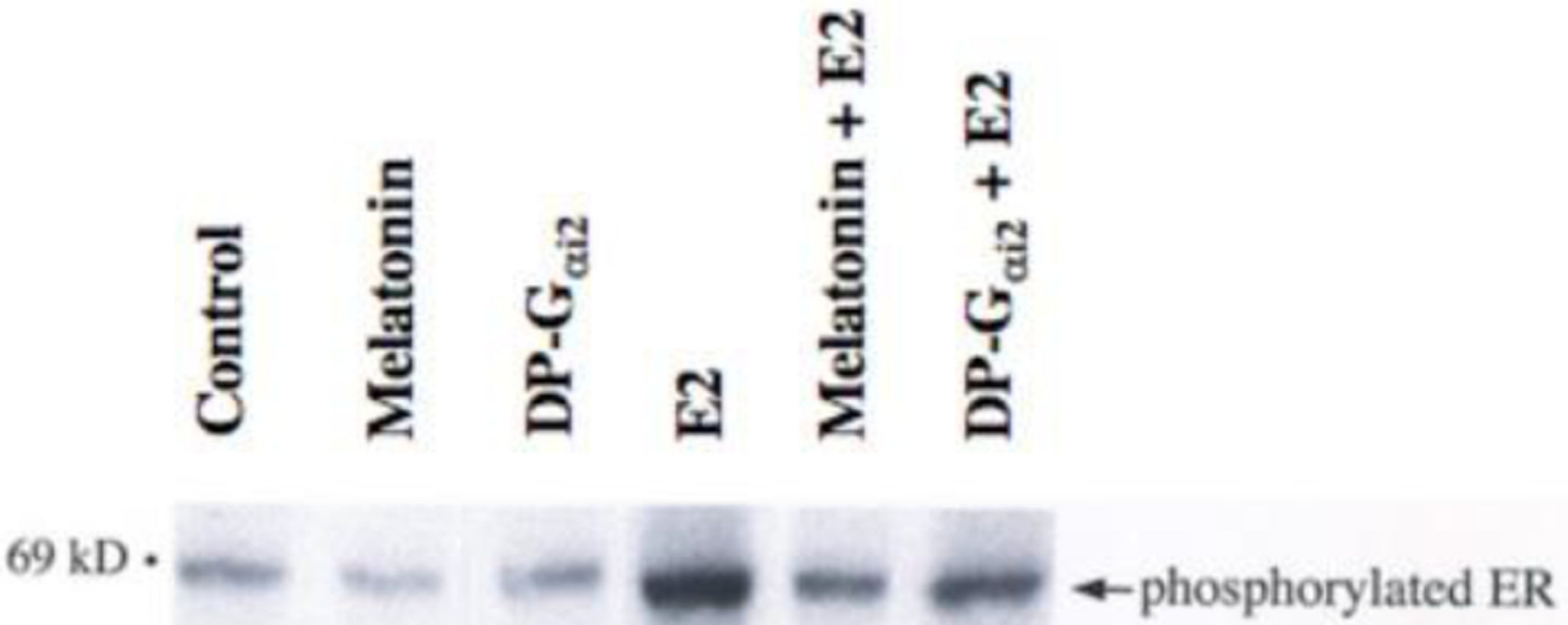

$46 \mathrm{kD} \cdot$

$69 \mathrm{kD}$.

$46 \mathrm{kD}$.

Fig. 3.

Modulation of ERa phosphorylation in MCF-7 breast cancer cells by $\mathrm{E}_{2}$, melatonin and a DP-G $\mathrm{G}_{\mathrm{ai} 2}$ protein. Immunoblot analysis of phosphorylated ERa in response to $\mathrm{E}_{2}(1 \mathrm{nM})$, melatonin $(10 \mathrm{nM})$ and expression of a DP-G $\mathrm{Gi}_{2}(50 \mathrm{mg} / \mathrm{well})$ cDNA. Phosphorylated ERa is on the top band and total ERa is the bottom band. 


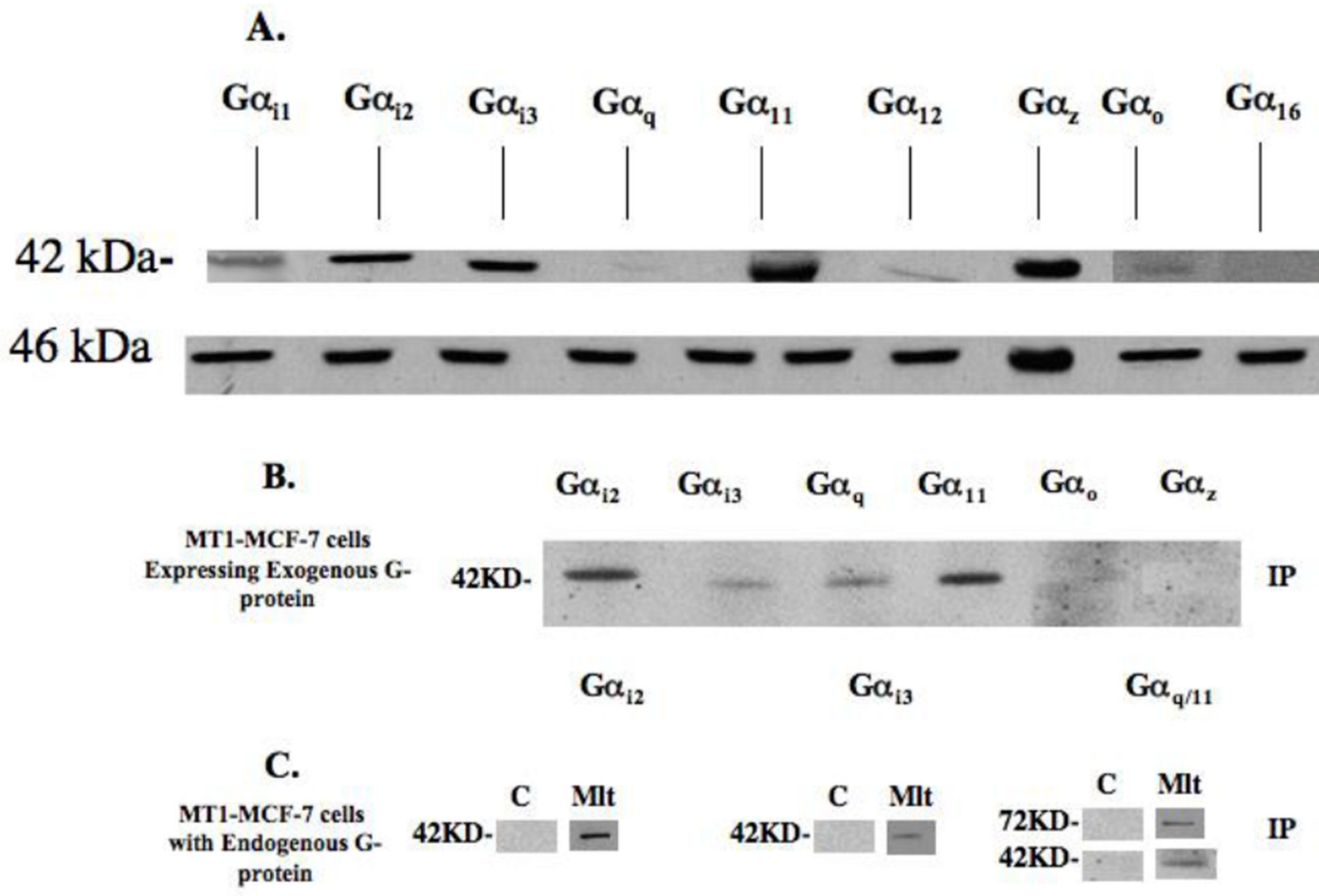

Fig. 4.

Expression of G proteins and MT1 receptor in MCF-7 breast cancer cells. (a) G-proteins expressed in MCF-7 cells. Seventy micrograms of total cellular protein from MCF-7 cells were loaded onto each lane. Specific G-proteins were detected using anti-G protein polyclonal rabbit antibodies $\left(\mathrm{G}_{\mathrm{ai} 2}, \mathrm{G}_{\mathrm{ai} 3}, \mathrm{G}_{\mathrm{aq}}, \mathrm{G}_{\mathrm{a} 11}, \mathrm{G}_{\mathrm{ao}}, \mathrm{G}_{\mathrm{az}}\right.$, and $\left.\mathrm{G}_{\mathrm{a} 12}\right)$, anti- $\mathrm{G}_{\mathrm{a} 16}$ goat polyclonal antibodies, or anti- $\mathrm{G}_{\mathrm{ai1}}$ mouse monoclonal antibody at a 1:1000 dilution. (b) MT1-MCF-7 cells were transiently transfected with wild-type G-protein $\left(\mathrm{G}_{\mathrm{ai} 2}, \mathrm{G}_{\mathrm{ai} 3}, \mathrm{G}_{\mathrm{aq}}\right.$, $\mathrm{G}_{\mathrm{a} 11}, \mathrm{G}_{\mathrm{aO}}, \mathrm{G}_{\mathrm{aZ}}, \mathrm{G}_{\mathrm{a} 12}, \mathrm{G}_{\mathrm{a} 16}$ and $\mathrm{G}_{\mathrm{ai1}}$ ) expression vectors for $24 \mathrm{~h}$, followed by treatment with $10 \mathrm{nM}$ melatonin. Lysates were immunoprecipitated with the anti-MT1 536 and protein A-agarose beads. (c) The extracts from the MT1-MCF-7 cells treated with either control vehicle (C) [0.001\% alcohol] or $1 \mathrm{nM}$ melatonin (Mlt) for $30 \mathrm{~min}$. were incubated with antiMT1 536 antibody for immunoprecipition. G-proteins coupled to the MT1 receptor were detected by immunoblot blot analysis, using specific anti-G-protein antibodies as described in Materials and Methods. 

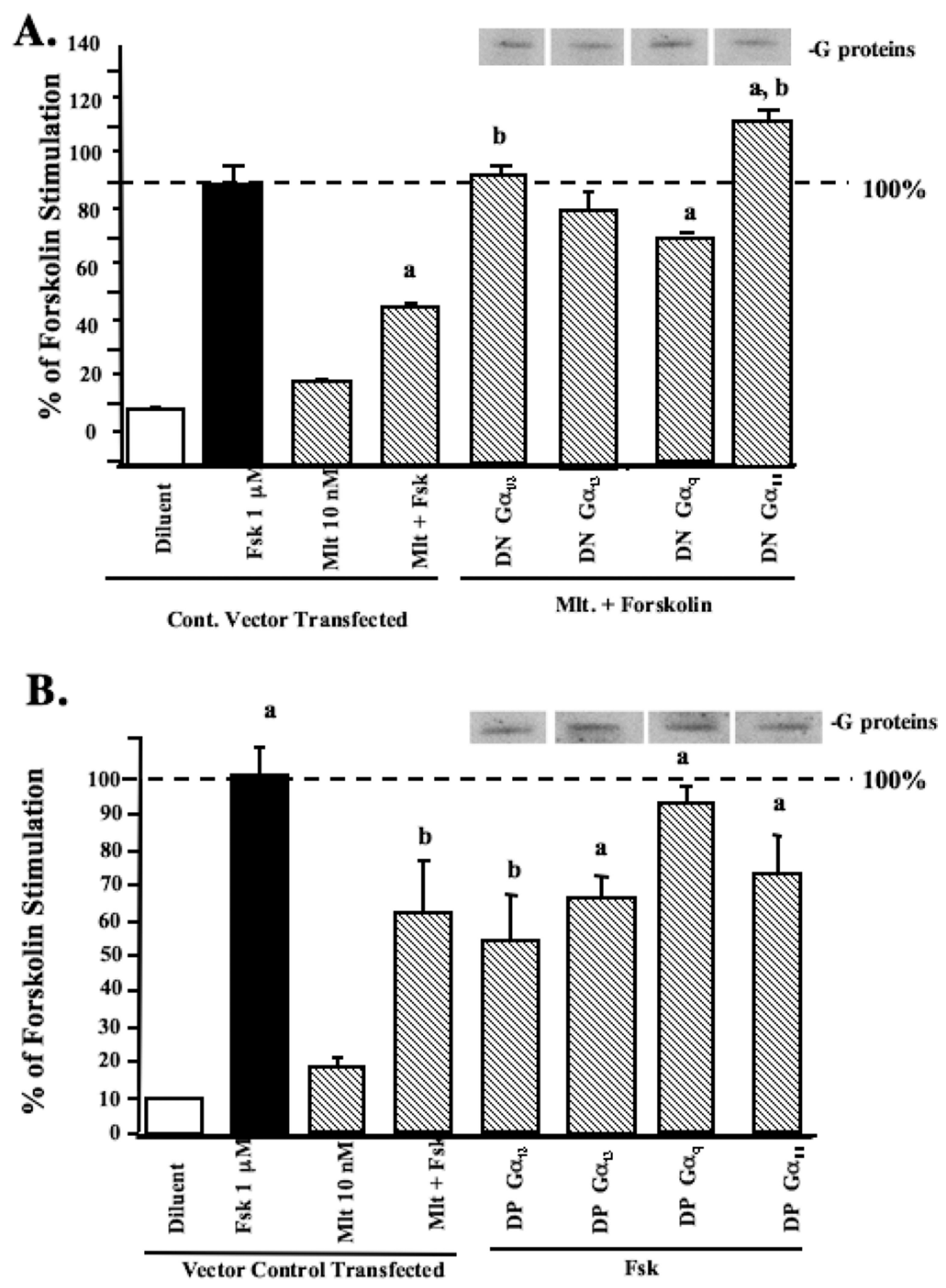

Fig. 5.

Modulation of forskolin-stimulated cAMP accumulation by melatonin in MCF-7 cells with transient expression of G-protein. (a) Modulation of forskolin-stimulated cAMP accumulation by melatonin in the cells expressing DN-G-proteins. Cells were transfected transiently with DN-G-protein expression constructs then treated as described in Materials and Methods. Cell extracts (1:1000 dilution) were analysized for cAMP levels using the cAMP- $\left[{ }^{125} \mathrm{I}\right]$ assay system as described in Materials and Methods. (b) Modulation of forskolin-stimulated cAMP accumulation in the cells expressing DP-G-proteins. Cell 
extracts (1:1000 dilution) were analyzed for cAMP levels as described above. Expression of DN-G-proteins and DP-G-proteins following transfection was evaluated by immunoblot analysis of duplicate cell lysates and expression is shown above the bar graph. Results are expressed as a percentage of Fsk stimulation. ( $\mathrm{n}=3$ experiments in triplicate for each group). a, $\mathrm{P}<0.05$ vs. control, b, $\mathrm{P}<0.05$ vs. Fsk). 

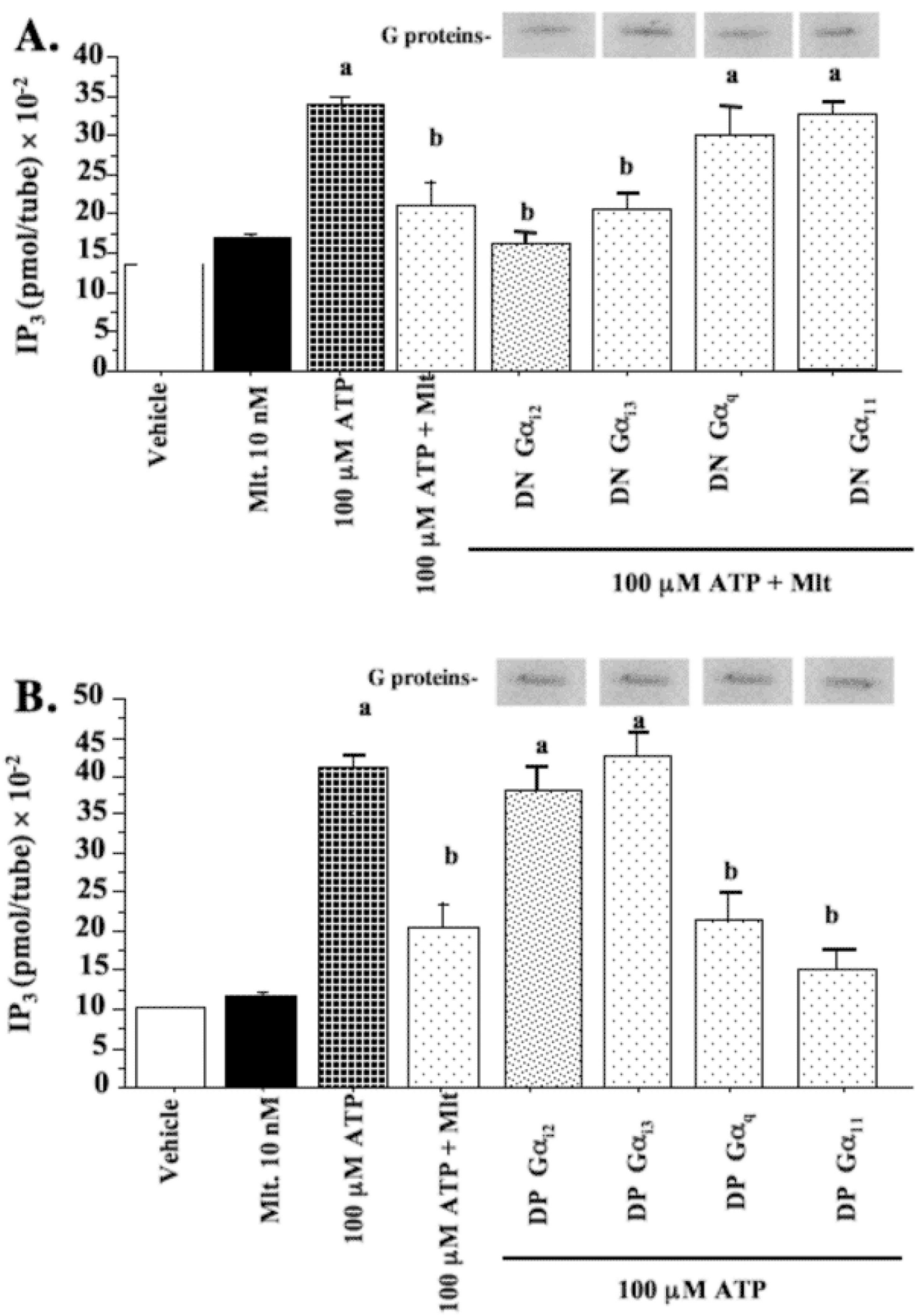

Fig. 6.

Modulation of ATP-stimulated $\mathrm{IP}_{3}$ levels by melatonin in MCF-7 cells. MCF-7 cells were transfected with DN-G proteins (a) or DP-G proteins $\left[\mathrm{Ga}_{\mathrm{i} 2}, \mathrm{Ga}_{\mathrm{i} 3}, \mathrm{Ga}_{\mathrm{q}}\right.$ and $\left.\mathrm{G}_{11}\right]$ (b) and treated with ATP. Following the plating, the cells were incubated for $20 \mathrm{~min}$ in $10 \mathrm{mM} \mathrm{LiCl}$, and then treated as described in Materials and Methods. Cell lysates were analyzed using the Inositol-1,4,5-triphosphate $\left(\mathrm{IP}_{3}\right)\left[{ }^{3} \mathrm{H}\right]$ assay system as described in Materials and Methods. Expression of DP-G-proteins following transfection was evaluated by immunoblot analysis of duplicate cell lysates and expression is shown above the appropriate bar graphs. The data 
is presented as the mean $\mathrm{IP}^{3}(\mathrm{pmol} / \mathrm{tube}) \times 10^{-2} \pm$ S.E.M. $\mathrm{n}=3$ independent experiments; a, $P$ $<0.05$ vs. control; $b, P<0.05$ vs. ATP. 

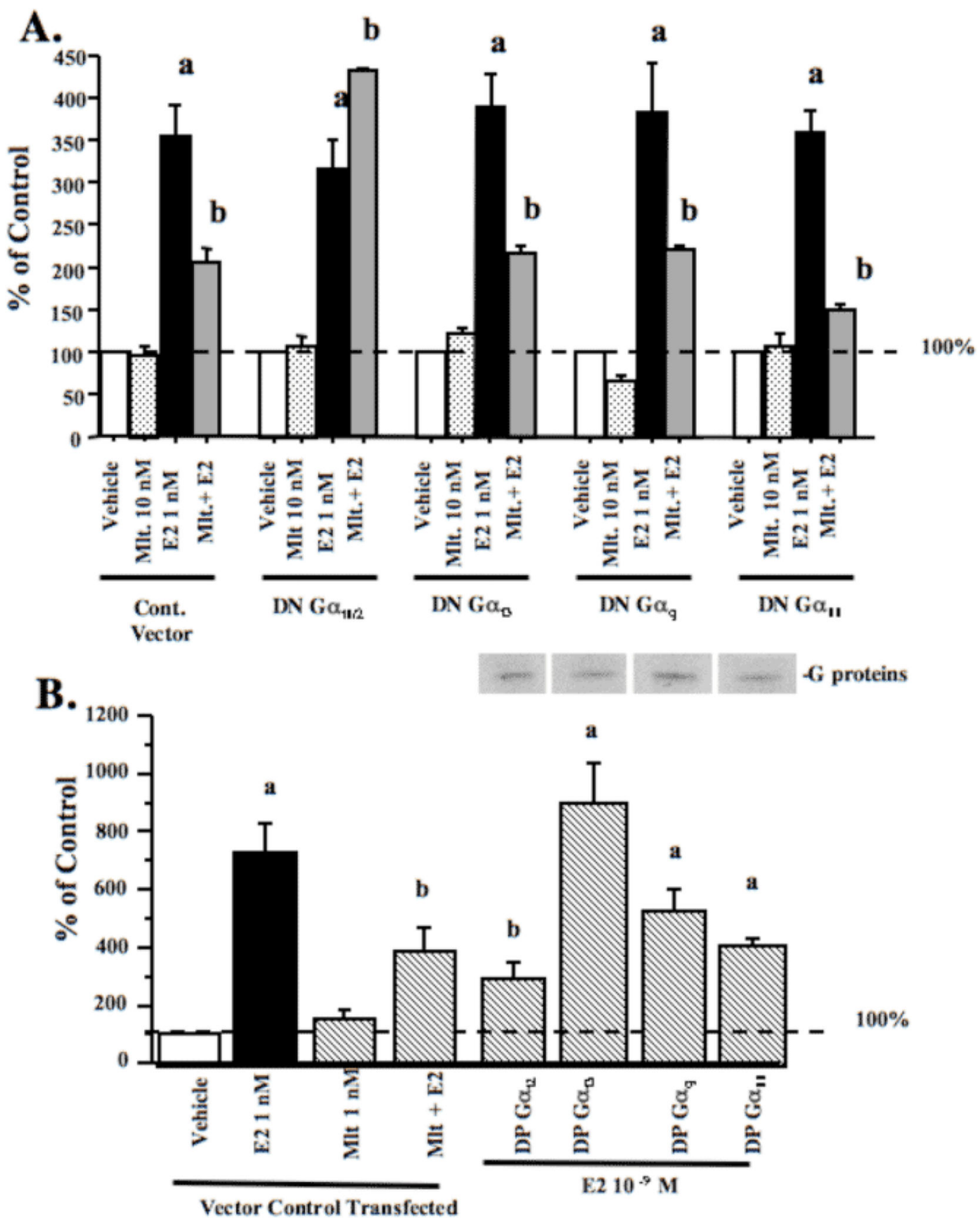

Fig. 7.

Effects of G-proteins on ERa transcriptional activity in MCF-7 cells.

MCF-7 cells were transiently transfected with an ERE-luciferase reporter construct and DNG-protein plasmids. (a) Cells were treated with vehicle $(0.001 \%$ ethanol), $10 \mathrm{nM}$ melatonin, $1 \mathrm{nM} \mathrm{E}_{2}$, or pretreated with melatonin for $30 \mathrm{~min}$ followed by $\mathrm{E}_{2}$ and harvested for luciferase assay. (b) Effects of on melatonin-mediated inhibition of ERa transcriptional activity in MCF-7 cells. Cells were treated as described above, but transfected with DP-Gprotein plasmids. Expression of DP-G-proteins following transfection was evaluated by 
immunoblot analysis of duplicate cell lysates and expression is shown above the bar graphs. For comparison purposes vector control diluent treated values were set at $100 \%$ and activity in response to other treatments was recorded as percent of control activity. $\mathrm{n}=3$ independent experiments; a, $P<0.05$ vs. control; $b, P<0.05$ vs. $\mathrm{E}_{2}$ alone. 

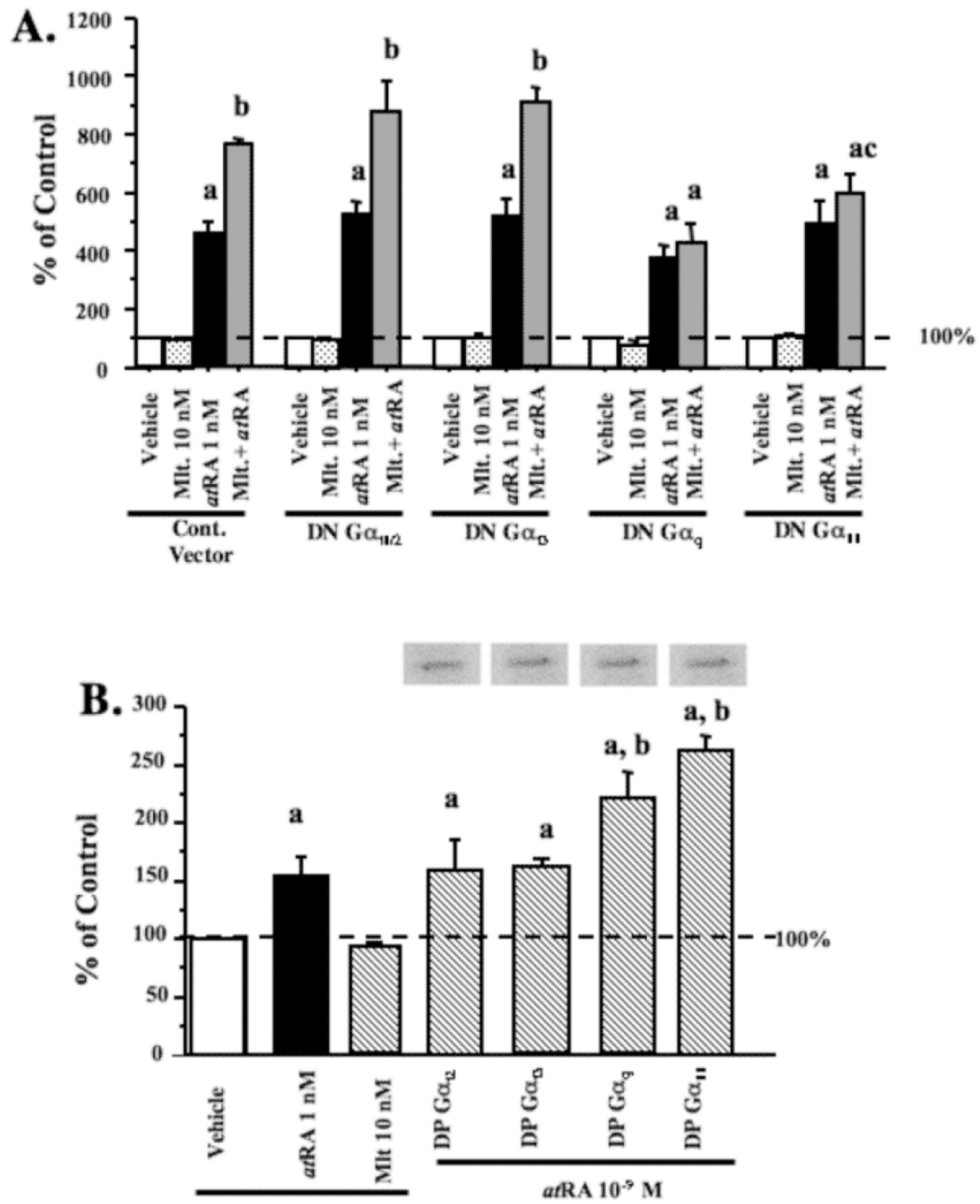

Vector Transfected Control

Fig. 8.

Effects of melatonin and DN/DP-G-proteins on RARa transcriptional activity in MCF-7 cells. (a) Effects of DN-G-proteins on melatonin-mediated enhancement of atRA-induced RARa transcriptional activity in MCF-7 cells. Cells were transiently transfected with RARE-luciferase reporter construct and DN-G-protein plasmids. Cells in medium supplemented with 5\% CS-FBS were treated for with vehicle (0.001\% ethanol), $10 \mathrm{nM}$ melatonin, $1 \mathrm{nM}$ atRA, or melatonin and atRA simultaneously. (b) Effects of DP-G-proteins on melatonin-mediated enhancement of RARa transcriptional activity in MCF-7 cells. Cells 
were transfected with an RARE as described above and DP-G-protein plasmids and treated with either vehicle $(0.001 \%$ ethanol) $10 \mathrm{nM}$ melatonin or $1 \mathrm{nM}$ atRA. Expression of DP-Gproteins was evaluated by immunoblot analysis is shown above the bar graphs. For comparison purposes vector control diluent treated values were set at $100 \%$ and activity in response to other treatments was recorded as percent of control activity. $\mathrm{n}=3$ independent experiments; a, $P<0.05$ vs. control; $b, P<0.05$ vs. atRA-stimulated vector controls. 

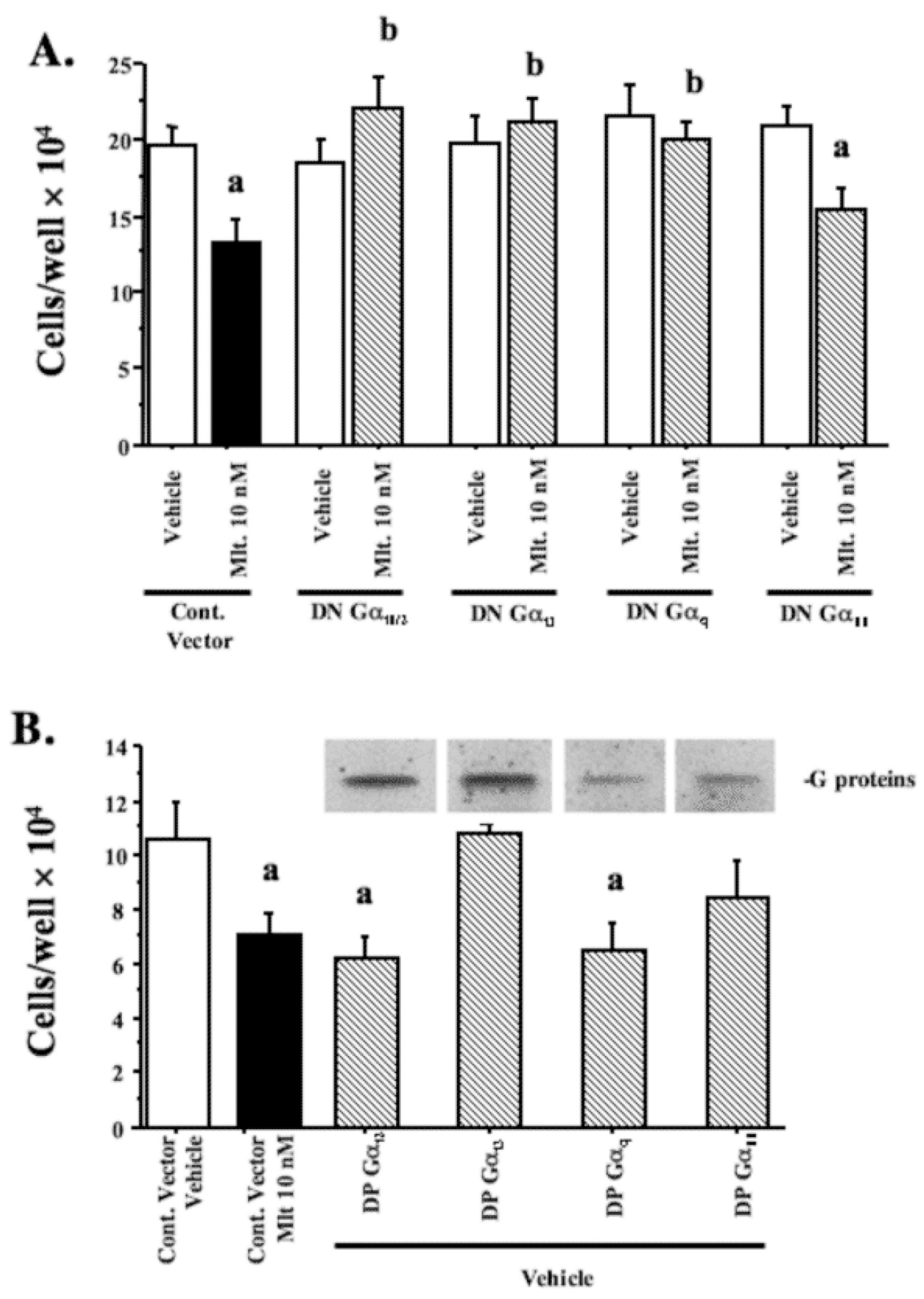

Fig. 9.

Growth-inhibitory effect of melatonin regulated by $\mathrm{Ga}_{\mathrm{i} 2}$ and $\mathrm{Ga}_{\mathrm{q}}$ proteins in MCF-7 cells. The MCF-7 cells were transiently transfected with control vector or (a) DN-G-protein plasmids for $8 \mathrm{~h}$ and then treated with $0.001 \%$ ethanol or $10 \mathrm{nM}$ melatonin for 7 days; (b) MCF-7 cells were transfected with DP-G-protein plasmids for and then treated with $0.001 \%$ ethanol for 7 days. Control cells include diluent treated controls $(0.001 \%$ ethanol) and melatonin $(10 \mathrm{nM})$ treated controls. Expression of DP-G-proteins was evaluated by immunoblot analysis is shown above the bar graphs. Viable cells as measured by trypan blue 
exclusion were counted using a hemocytometer. The results represent the mean cell number $\times 10^{4} /$ well \pm S.E.M. of data from at least three independent experiments each performed in triplicate; a, $P<0.05$ vs. control; $b, P<0.05$ vs. melatonin treated. 